\title{
アンダーマッチング溶接による高強度鋼組立部材を用いた 方杖ダンパー接合構造の力学的性能と地震応答性状 MECHANICAL PERFORMANCE AND SEISMIC RESPONSE OF KNEE BRACE DAMPER STRUCTURE OF H-SA700 HIGH STRENGTH STEEL MEMBERS MADE BY UNDERMATCHED WELDS
}

\author{
新 才直 紀*, 吹田 啓一郎**, 聲 高 裕治*** \\ Naoki SHINSAI, Keiichiro SUITA and Yuji KOETAKA
}

\begin{abstract}
This paper presents results of loading tests of $\mathrm{H}-\mathrm{SA} 700$ high strength steel structures in which beams and columns are made by undermatched welds and constructed by knee brace dampers. The feasibility of high strength bolted joints of high strength steel members with knee brace dampers and mechanical performance of the beam-column subassemblages are verified by loading tests. The advantage of high strength steel is verified by examples of the design of structures and the results of time history response analyses comparing with the structures made by usual mild steel.
\end{abstract}

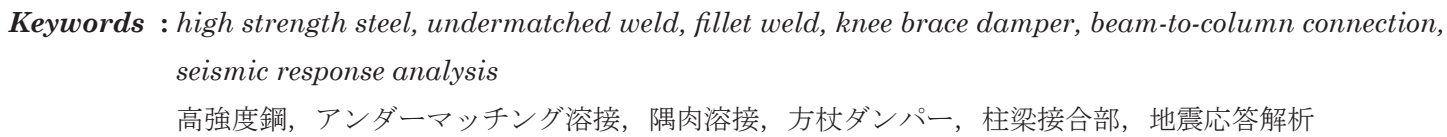

1. 序

建築構造物の長寿命化や耐震性能の向上を目標として，平成 16 年 度より府省連携プロジェクト「革新的構造材料を用いた新構造シス テム建築物」に関する研究が行われ ${ }^{1), 2)}$ ，建築構造用高強度 $780 \mathrm{~N} /$ $\mathrm{mm}^{2}$ 鋼材（H-SA700）が開発された。この鋼材は従来の鋼材の 2 倍程の強度を有しており, 降伏比が $98 \%$ 以下と規定されているため, 弾性範囲での使用が前提となる．溶接性の違いによって A 材と B 材 があり，A材は隅肉溶接が可能であるが，完全溶込み溶接に対して は耐力を期待することができず，B材は完全溶込み溶接による接合 が可能とされている.

現在この高強度鋼による圧延形鋼は製造されていないため，この 鋼材を利用するには，鋼板を集成して構造システムに用いる鋼部材 を製作する必要がある．既往の研究では次の 2 つの方法が検討され ている.

(1) B 材と高強度鋼に見合うだけの強度を有する溶接材料を用いた完 全溶込み溶接による接合法 $\left.{ }^{3)} \sim 10\right)$

(2)高力ボルトのみを接合に用いる乾式接合法（A 材を使用） 11) 14) しかし(1)は高強度鋼と同等の強度の溶接材料を用いるため, 溶接管 理に高い技能とコストが必要である。(2)に関しては，部材を製作す るために高強度鋼に曲げ加工や多くのボルト孔が必要であり, BH 形
鋼よりも施工工程が多くなることは避けがたい.

それらに対して, 筆者ら（文献 15)，16)）は高強度鋼（H-SA700） に既往の鋼材に使用している溶接材料 G59JA1UC3M1T（JIS Z3312, 以下 G59J と称寸) を用いて, 母材より強度の低い溶接（ア ンダーマッチング溶接）を適用することを提案した。 アンダーマッ チング溶接は，完全溶込み溶接部に母材と同等の耐力を与えること は難しいが，サイズで強度を調節可能な隅肉溶接に適用することが できる，文献 15)，16) では，溶接継目に溶接材料の強度を超える応 力が作用しないように設計することで，必要な強度の溶接組立部材 や接合部を実現する方法を示した.

本論文では，アンダーマッチング溶接による高強度鋼組立部材を 活か寸骨組として，柱梁に高強度鋼組立部材を用い，それらを方杖 ダンパーを介して高力ボルト接合する骨組（方杖ダンパー接合構造） を対象とする．方杖ダンパー接合構造は高力ボルト接合を主体とし， 地震荷重に対して柱梁を弾性に留め, 座屈拘束型の方杖ダンパーの みが塑性化するように設計するため，鋼構造骨組に安定した施工品 質と高い塑性変形能力を付与できる柱梁接合形式である ${ }^{17)}$. 高強度 鋼を用いた純ラーメン構造を耐力の条件だけで設計すると柱梁部材 断面が小さくなり，変形が増大寸るため，方杖ダンパーを用いるこ とで骨組の剛性を高めることができる，本論文では，部分架構実験
* 京都大学大学院工学研究科建築学専攻 修士課程

** 京都大学大学院工学研究科建築学専攻 教授・博士 (工学)

*** 京都大学大学院工学研究科建築学専攻 准教授. 博士 (工学)
Graduate Student, Dept. of Architecture and Architectural Engineering, Kyoto Univ. Prof., Dept. of Architecture and Architectural Engineering, Kyoto Univ., Dr. Eng. Assoc. Prof., Dept. of Architecture and Architectural Engineering, Kyoto Univ., Dr. Eng. 
によりその力学的性能を確認し, 試設計により高強度鋼を使用する 構造的な利点を分析する

\section{2. 部分架構実験で用いる鋼材と溶接材料の要素試験}

\section{1 鋼材材料試験}

3 章で示す方杖ダンパー接合構造の部分架構実験に先立ち, 試験体 の柱梁に適用した高強度鋼（H-SA700B，板厚 $16 ， 19 \mathrm{~mm})$ ，方杖 ダンパーの芯材 (SN400B, $\mathrm{S}$ 型 : $25 \mathrm{~mm}, \mathrm{D}$ 型 : $19 \mathrm{~mm}$ ), 接合ア ングル（S 型：SN490B，36mm，D 型：SS400，25mm）の引張試 験を行った。ここで， $\mathrm{S}$ 型とは方杖ダンパーを梁の下側のみに設置 する形式を，D型とは方杖ダンパーを梁の上下に設置する形式を表 している.

試験片は JIS Z2201 1A 号試験片とし，本数は鋼種・板厚ごとに 2 本とする. 2 体の試験片より得られた降伏点 ${ }_{s} \sigma_{y}$, 引張強さ ${ }_{s} \sigma_{u}$ の平 均值を表 1 に実測值として示す．また表 1 にこれらの鋼材の降伏点 ${ }_{s} \sigma_{y}$, 引張強さ ${ }_{s} \sigma_{u}$ の規格下限值を併記する. 図 1 に $\mathrm{H}-\mathrm{SA} 700 \mathrm{~B}$ (板 厚 $19 \mathrm{~mm}$ ) の応力ーひずみ関係を例示する. (a) 図はひずみ硬化域 $(4 \%$ 程度）を示し，(b) 図は破断までを示寸，高強度鋼は降伏点が不明確 であったため, $0.2 \%$ オフセット法により求めた.

\section{2 溶接金属引張試験}

\section{2.1 溶接管理条件}

溶接材料には，高強度鋼どうしの接合（BH 形鋼のウェブフィレッ 卜部）には G59J を用い, 高強度鋼と従来鋼の接合（スチフナの接合） には YGW18 を用いた. G59J およびYGW18 の降伏点と引張強さの 規格值を表 2 に示寸，それぞれの溶接材料の溶接管理条件は，G59J

表 1 試験体鋼材の機械的性質

\begin{tabular}{|c|c|c|c|c|c|c|}
\hline \multirow{3}{*}{ 鋼種 } & \multirow{3}{*}{$\begin{array}{c}\text { 板厚 } \\
{[\mathrm{mm}]}\end{array}$} & \multicolumn{3}{|c|}{ 降伏点 $\left[\mathrm{N} / \mathrm{mm}^{2}\right]$} & \multicolumn{2}{|c|}{ 引張強さ $\left[\mathrm{N} / \mathrm{mm}^{2}\right]$} \\
\hline & & \multirow{2}{*}{$\begin{array}{c}\text { 規格 } \\
\text { 下限値 }\end{array}$} & \multicolumn{2}{|c|}{ 実測值 } & \multirow{2}{*}{$\begin{array}{c}\text { 規格 } \\
\text { 下限値 } \\
\end{array}$} & \multirow{2}{*}{ 実測值 } \\
\hline & & & 下降伏点 & 上降伏点 & & \\
\hline \multirow{2}{*}{$\mathrm{H}-\mathrm{SA} 700 \mathrm{~B}$} & 16 & \multirow{2}{*}{700} & & 777 & \multirow{2}{*}{780} & 832 \\
\hline & 19 & & 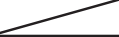 & 800 & & 833 \\
\hline \multirow{2}{*}{ SN400B } & 25 & \multirow{2}{*}{235} & 274 & 289 & \multirow{2}{*}{400} & 430 \\
\hline & 19 & & 278 & 292 & & 443 \\
\hline SN490B & 36 & 325 & 334 & 350 & 490 & 518 \\
\hline SS400 & 25 & 235 & 262 & 278 & 400 & 432 \\
\hline
\end{tabular}

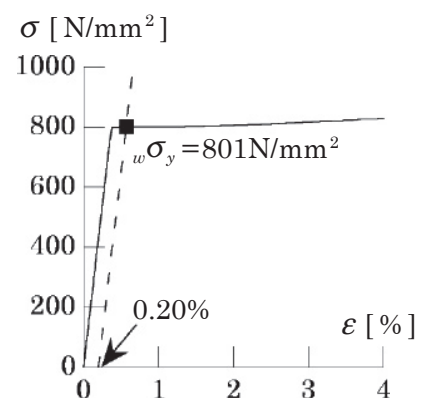

(a)

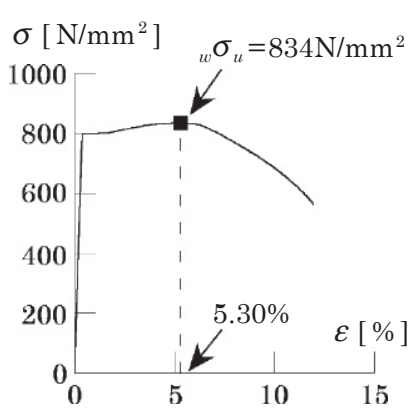

(b)
図 $1 \mathrm{H}-\mathrm{SA} 700 \mathrm{~B}$ (板厚 19mm) の応力ひずみ関係

表 2 G59J, YGW18 の規格值及び溶接管理条件

\begin{tabular}{|c|c|c|c|c|c|}
\hline $\begin{array}{c}\text { 溶接 } \\
\text { 材料 }\end{array}$ & $\begin{array}{c}\text { 降伏点 } \\
{\left[\mathrm{N} / \mathrm{mm}^{2}\right]}\end{array}$ & $\begin{array}{c}\text { 引張強さ } \\
{\left[\mathrm{N} / \mathrm{mm}^{2}\right]}\end{array}$ & $\begin{array}{c}\text { 予熱 } \\
{\left[{ }^{\circ} \mathrm{C}\right]}\end{array}$ & $\begin{array}{c}\text { 入熱 } \\
{[\mathrm{kJ} / \mathrm{cm}]}\end{array}$ & $\begin{array}{c}\text { パス間温度 } \\
{\left[{ }^{\circ} \mathrm{C}\right]}\end{array}$ \\
\hline G59J & 500 以上 & $590 \sim 790$ & $\geq 100$ & $\leq 30$ & $\leq 350$ \\
\hline YGW18 & 460 以上 & $550 \sim 740$ & $\geq 100$ & $\leq 40$ & $\leq 250$ \\
\hline
\end{tabular}

では母材が SA440 の溶接施工指針 ${ }^{18)}$ を，YGW18 では JIS Z3312の 解説に示される引張強さ $490 \mathrm{~N} / \mathrm{mm}^{2}$ 級の溶接管理条件を参考に表 2 のように定めた．隅肉溶接のパス数は設計時のサイズが $6 \sim 10 \mathrm{~mm}$ は 1 パス, $11 \mathrm{~mm}$ は 2 パス, $12 \mathrm{~mm}$ は 3 パスとする.

\section{2.2 試験方法}

隅肉溶接継目から丸棒試験片を削り出して溶接金属の引張試験 (WBH) を行った。試験片は図 2 に示寸板厚 $19 \mathrm{~mm}$ の H-SA700B を G59Jにより両面隅肉溶接した T 継手から削り出したものである.

800

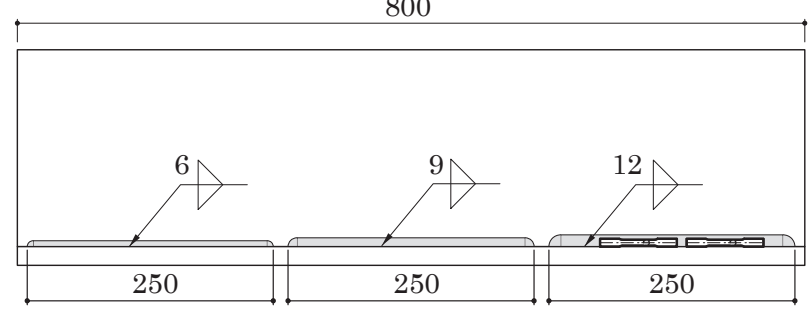

(a) 試験片採取用隅肉溶接

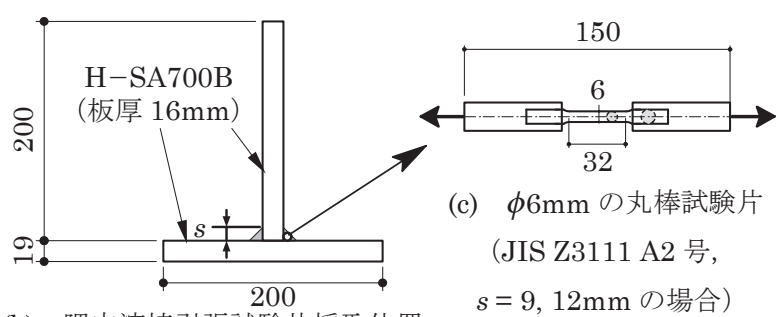

(b) 隅肉溶接引張試験片採取位置

図 $2 \mathrm{WBH}$ 試験体（単位 $[\mathrm{mm}]$ )

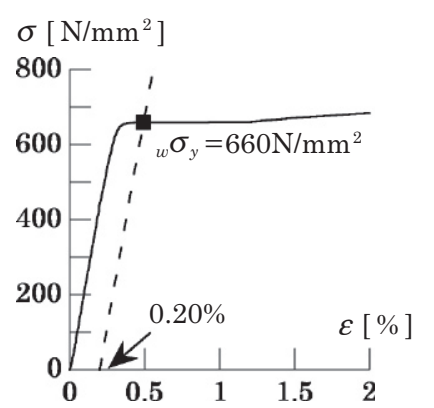

(a)

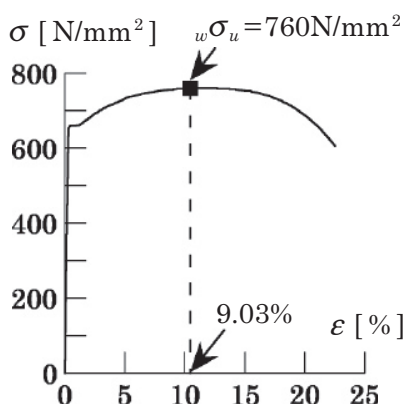

(b)
図 $3 \mathrm{WBH}(s=9 \mathrm{~mm})$ の応力ひずみ関係

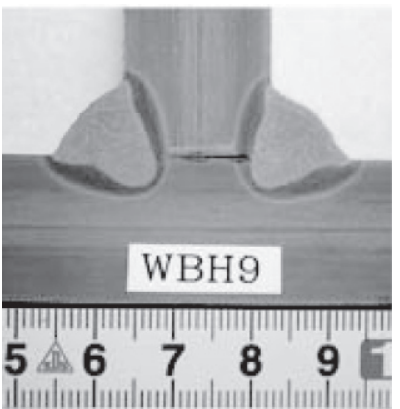

写真 1 マクロ写真 $(s=9 \mathrm{~mm})$

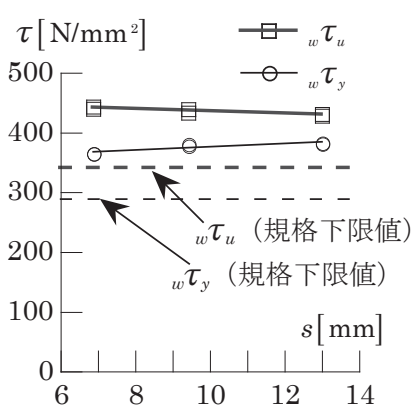

図 $4 \quad \mathrm{WBH} \quad \tau-s$ 関係
表 $3 \mathrm{WBH}$ 溶接管理条件の記録

\begin{tabular}{|c|c|c|c|c|}
\hline \multicolumn{2}{|c|}{ 隅肉サイズ [mm] } & \multirow{2}{*}{ パス数 } & \multirow{2}{*}{$\begin{array}{c}\text { 入熱量 }[\mathrm{kJ} / \mathrm{cm}] \\
\text { 最大值 } \\
\end{array}$} & \multirow{2}{*}{$\begin{array}{c}\text { パス間温度 }\left[{ }^{\circ} \mathrm{C} \text { ] }\right. \\
\text { 最大值 } \\
\end{array}$} \\
\hline 設計值 & 実測值 & & & \\
\hline 6 & 6.88 & 1 & 16.2 & - \\
\hline 9 & 9.42 & 1 & 25.1 & - \\
\hline 12 & 13.0 & 3 & 14.3 & 180 \\
\hline
\end{tabular}


試験片は隅肉溶接のサイズ $s$ が $6,9 ， 12 \mathrm{~mm}$ のものからそれぞれ 2 本ずつ採取し， $s$ が $6 \mathrm{~mm}$ の場合は $\phi 3 \mathrm{~mm}$ の丸棒（JIS Z2201 14A 号に準ずる)， $s$ が $9,12 \mathrm{~mm}$ の場合は $\phi 6 \mathrm{~mm}$ の丸棒 (JIS Z3111 A2 号）とする. 両端つか夕部はネジ加工してアタッチメントを取 り付けて引張試験を行った。 また隅肉溶接の溶込み量を確認するた め，マクロ試験を行った。マクロ写真の一例（ $s=9 \mathrm{~mm}$ の場合）を写 真 1 に示寸. また隅肉サイズと溶接管理条件の実測值を表 3 に示寸.

\subsection{3 試験結果}

実験から得られた応力 -ひずみ関係の一例（ $s=9 \mathrm{~mm}$ の場合）を 図 3 に示す. (a) 図はひずみ硬化域（2\% 程度）を示し，(b) 図は破断 までを示す，降伏点が不明確であったため， $0.2 \%$ オフセット法によ り求めた。 実験より得られた降伏点と引張強さを $\sqrt{3}$ で除して, 降 伏せん断応力 ${ }_{w} \tau_{y}$ と最大せん断応力 ${ }_{w} \tau_{u}$ とし, 各試験体の ${ }_{w} \tau_{y},{ }_{w} \tau_{u}$ と隅肉溶接のサイズ $s$ の関係を図 4 に示す。ここで, 隅肉溶接のサ イズには両面隅肉溶接の両方の脚長を一つの溶接線に対し 3 箇所計 測し，その平均值を用いる．以降の実験に関しても同様の手法で隅 肉サイズを測定している. 図 4 には実験結果の回帰分析結果, 各溶
接材料の ${ }_{w} \tau_{y},{ }_{w} \tau_{u}$ の規格下限值を併記する.

図 4 より，実験から得られた ${ }_{w} \tau_{y},{ }_{w} \tau_{u}$ はいずれも規格下限值を十 分に上回っており，文献 $15 ， 16)$ と同様の結果となっている.この 実験から G59J の隅肉溶接のサイズと強度の実測值の関係を見ると サイズの影響は非常に小さいので，以後の計算ではサイズによらず 平均值 $\left({ }_{w} \tau_{y}=376 \mathrm{~N} / \mathrm{mm}^{2},{ }_{w} \tau_{u}=436 \mathrm{~N} / \mathrm{mm}^{2}\right)$ を用いる.

\section{3. 方杖ダンパー接合構造の部分架構実験}

\section{1 実験方法}

方杖ダンパー接合構造の柱梁にアンダーマッチング溶接（G59J） による高強度鋼（H-SA700B）組立部材を使用した場合の力学的性 能を確認するために，部分架構実験を行った。試験体は図 5 に示す 卜字形骨組で，下フランジ側のみに方杖ダンパーを配置した S 型と 梁の上下に配置した $\mathrm{D}$ 型の 2 種類である. 梁端部は上フランジの表 裏に接合アングル（図 6）を設置し，柱フランジと接合する. 梁下フ ランジ側には構面外の移動を拘束するために, $9 \mathrm{~mm}$ の鋼板を曲げ加 工して製作した横補剛アングルを高力ボルト接合する.

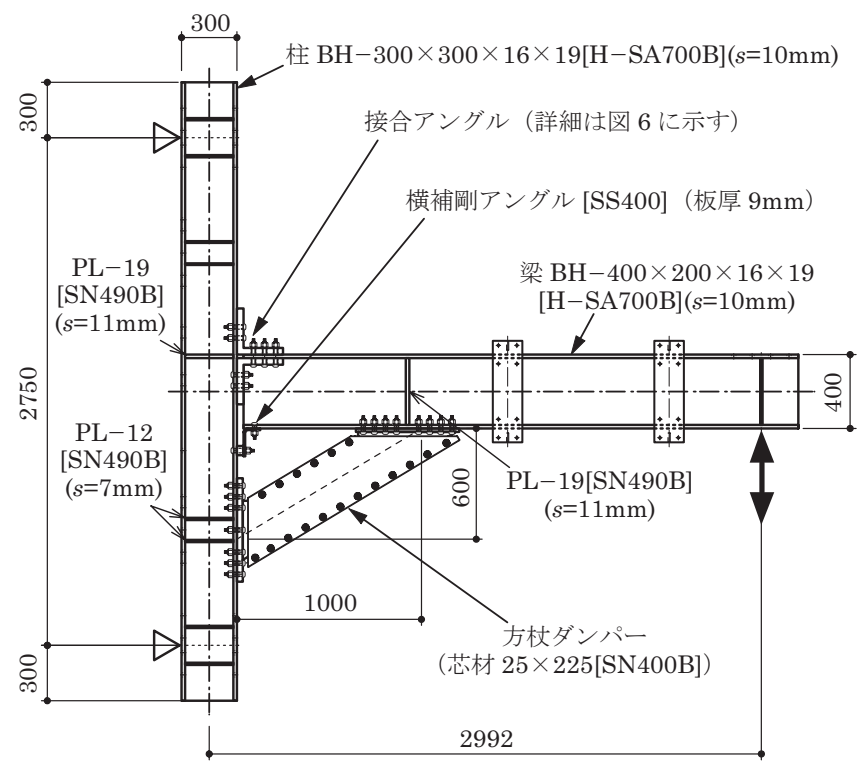

(a) $\mathrm{S}$ 型

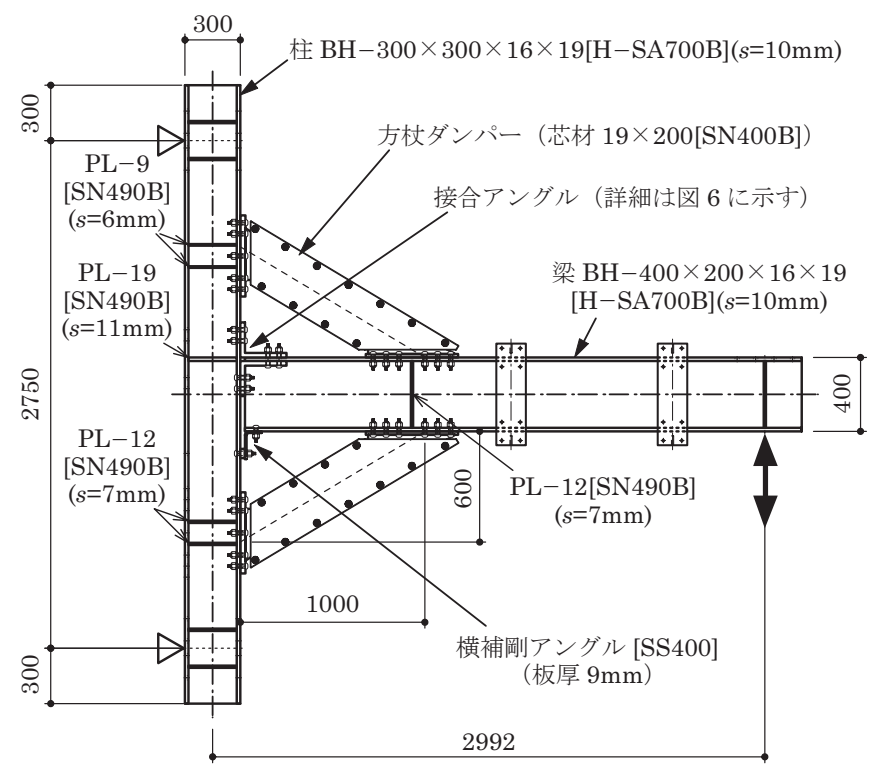

(b) $\mathrm{D}$ 型

図 5 試験体図面（単位 $[\mathrm{mm}]$, 図中の $s$ はその部材の接合に用いる隅肉溶接のサイズを示す）
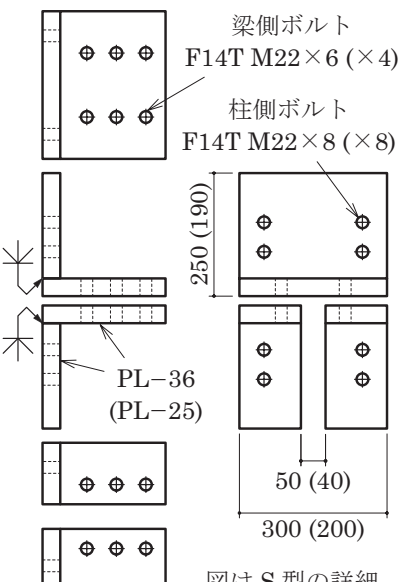

$250(250)$

図 6 接合アングル (単位 $[\mathrm{mm}]$

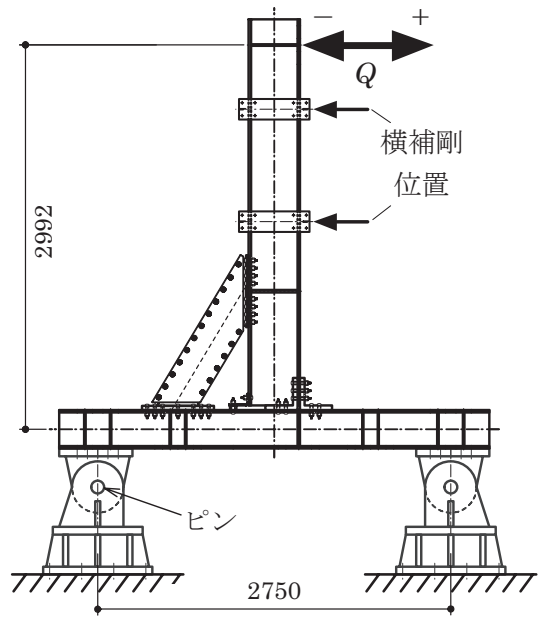

図 7 試験体設置図 ( $\mathrm{S}$ 型)

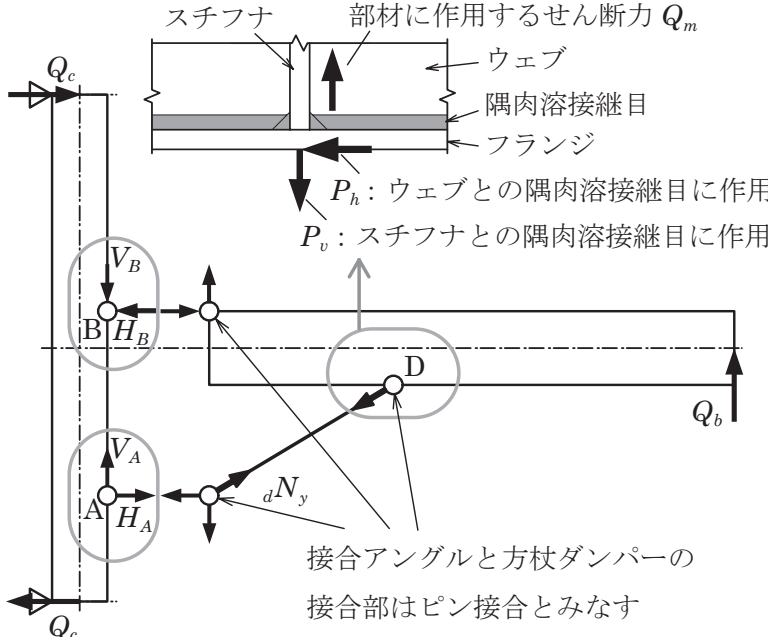

図 8 各部材および溶接継目に作用する力（ $\mathrm{S}$ 型） 
載荷は骨組の層間変形角で制御し, 図 7 の装置で $0.01 \mathrm{rad}$ を 1 回, $0.02,0.03,0.04 \mathrm{rad}$ を 2 回ずつ正負交番に漸増させ，その後は方杖 ダンパーの軸方向ひずみの值を確認しながら繰返し載荷を行う.

\section{2 試験体の設計}

図 5 に示すように柱・梁の長さと方杖ダンパーの水平・鉛直長さ を定め, 柱, 梁, 接合アングル, 横補剛アングル, 方杖ダンパーの 座屈拘束材と各部材の接合部を文献 17)，19），20）に基づき，柱梁 に従来鋼を用いた方杖ダンパー接合構造と同様の手順で設計する.

まず柱梁はダンパーの軸力が $1.1_{d} N_{y}\left({ }_{d} N_{y}\right.$ : ダンパー芯材の降伏軸 力）のときにボルト孔欠損を考慮した有効断面において降伏曲げ耐 カ以下となるように断面を設計する. また，ダンパーやアングルの 接合部はダンパーの軸力が $1.4_{d} N_{y}$ のときにボルト接合部の寸べりや 離間, アンダーマッチング溶接継目のせん断降伏, エンドプレート・ アングル・フランジの面外曲げ降伏, スチフナの座屈が生じないよ うに設計する，ここで，接合部設計用の接合部係数（1.4）は，鋼材 の降伏点のばらつきによる（1.15）と歪硬化によるダンパー芯材の 軸力上昇（1.2）を考慮して設定している. さらに座屈拘束材はダン パーの軸力が $1.5_{d} N_{y}$ のときに全体座屈や局部崩壊が生じないように それぞれ設計する，このうち，柱・梁に配置するスチフナの設計は 文献 21)によるものとする.

柱・梁のウェブフィレット部のアンダーマッチング溶接継目と柱・ 梁とスチフナの溶接継目に関して以下に設計方法を示す。ここでは $\mathrm{S}$ 型の設計方法についてまとめるが， $\mathrm{D}$ 型も同様の手順で設計する. 図 8 のように部材に力が作用するため, 柱の溶接継目は A, B 点, 梁の溶接継目は D 点に作用する力に対して設計する. 各点に作用す る力のうち溶接継目に平行方向に作用寸る力 $P_{h}$ と垂直方向に作用寸 る力 $P_{v}$ にわけて考え, $P_{h}$ にウェブフィレット部の溶接継目が抵抗し, $P_{v}$ にスチフナとフランジ, ウェブの溶接継目が抵抗すると考える.

まず柱・梁のウェブフィレット部の溶接継目には部材のせん断力 $Q_{m}$ と $P_{h}$ によってせん断応力 ${ }_{d w} \tau_{1}$ と ${ }_{d w} \tau_{2}$ が作用している. 両者の和 に対して溶接継目がせん断降伏応力 ${ }_{w} \tau_{y}$ に達しないように設計する. ${ }_{d w} \tau_{1},{ }_{d w} \tau_{2}$ は次式で求める.

$$
\begin{aligned}
{ }_{d w} \tau_{1} & =\frac{Q_{m} \cdot S_{f}}{2 I\left(s_{w} / \sqrt{2}\right)} \\
{ }_{d \omega} \tau_{2} & =\frac{P_{h}}{2 w_{d}\left(s_{w} / \sqrt{2}\right)}
\end{aligned}
$$

ここで, $I$ は部材の断面二次モーメント, $S_{f}$ は $\mathrm{H}$ 形断面の図心を含 む強軸まわりの片側フランジの断面一次モーメント, $s_{w}$ はウェブフィ レット部の溶接継目のサイズ, $w_{d}$ は有効な溶接長で, 高力ボルト接 合を介してカが伝達される範囲に対応してフランジに取り付けるボ ルト群の最外縁のボルト間距離を取る.

次にスチフナとフランジ，スチフナとウェブ間の溶接継目の設計 を行う. $P_{v}$ によってスチフナとフランジ間の溶接継目にせん断応力
${ }_{d s} \tau_{f}, \quad$ スチフナとウェブ間の溶接継目にせん断応力 ${ }_{d s} \tau_{w}$ が作用してい るものと考える. ${ }_{d s} \tau_{f}, d_{d s} \tau_{w}$ がそれぞれせん断降伏応力 ${ }_{w} \tau_{y}$ に達しな い上う隅肉溶接のサイズを決める. ${ }_{d s} \tau_{f},{ }_{d s} \tau_{w}$ は次式で求められる.

$$
\begin{aligned}
{ }_{d s} \tau_{f} & =\frac{P_{v}}{4 m \cdot 1.4 w_{s f}\left(s_{s f} / \sqrt{2}\right)} \\
{ }_{d s} \tau_{w} & =\frac{P_{v}}{4 m \cdot w_{s w}\left(s_{s w} / \sqrt{2}\right)}
\end{aligned}
$$

ここで, $s_{s f}, w_{s f}$ はスチフナとフランジ間の隅肉溶接継目のサイズと 溶接長, $s_{s w}, w_{s w}$ はスチフナとウェブ間の隅肉溶接継目のサイズと 溶接長, $m$ はスチフナの枚数を示す.

(1), (2) 式から求められる隅肉溶接継目のサイズの必要值（式中の $P_{h}, P_{v}, Q_{m}$ は $1.4_{d} N_{y}$ に対応寸る值である) と設計值を表 4 に示寸. また溶接継目以外に関して設計の結果得られた試験体の耐力計算値 （材料強度には実測值を使用）を表 5 に示す.

\section{3 実験結果}

\section{3. 1 S 型試験体結果}

図 9 に $\mathrm{S}$ 型試験体の載荷荷重 $Q$ (ダンパーが降伏軸力 ${ }_{d} N_{y}$ に達す るときの載荷荷重 $Q_{y}$ で無次元化）- 層間変形角 $R$ 関係を, 図 10 に $Q / Q_{y}$ - 方杖ダンパーの軸方向ひずみ $\varepsilon_{d}$ (ダンパーの平行部の長さで 算出）関係を示す．また表 5 に接合アングルと梁フランジ間の主す ベり発生前の最大荷重と実験全体の最大荷重を示す.

図 9 より, 初期剛性は図中に直線で示寸計算值 69.7[1/rad] に対し て, 実験值は 78.6[1/rad] で $13 \%$ 高い. $Q_{y}$ に達した辺りから剛性が 低下し, 柱梁が弾性のまま方杖ダンパーのみが塑性化し, 層間変形 角 $R$ が $0.02 \mathrm{rad}$ まで接合部にすべり等は生じておらず，安定した紡 錘形の挙動が確認できる. その後 $R=-0.03 \mathrm{rad} の 1$ 回目の載荷中に 接合アングルと梁フランジ間で主すべりが生じた。すべりが発生す る前の最大荷重は $571 \mathrm{kN}$ であり, すべり耐力の計算值 ${ }_{a} S_{b}(625 \mathrm{kN})$ を 1 割ほど下回っている.これは接合アングルが受ける曲げに対して, 接合アングルと梁フランジの材間圧縮力が低下したことに起因して いるものと考えられる.これは高強度鋼の梁と従来鋼の接合アング ルの組合せにより，相対的に接合アングルの剛性が高くなり，変形 に追従しにくくなったものと考えられる.すべり発生までのダンパー

\begin{tabular}{|c|c|c|c|c|c|c|c|c|c|}
\hline & \multirow{2}{*}{ 位置 } & \multirow{2}{*}{$\begin{array}{c}P_{h} \\
{[\mathrm{kN}]}\end{array}$} & \multirow{2}{*}{$\begin{array}{c}P_{v} \\
{[\mathrm{kN}]}\end{array}$} & \multirow{2}{*}{$\begin{array}{c}Q_{m} \\
{[\mathrm{kN}]}\end{array}$} & $s_{w}$ & $s_{s f}$ & $s_{s w}$ & $s_{w}$ & $s_{s f}, \quad s_{s w}$ \\
\hline & & & & & \multicolumn{3}{|c|}{ 必要值 [mm] } & \multicolumn{2}{|c|}{ 設計值 [mm] } \\
\hline \multirow{3}{*}{$\mathrm{S}$ 型 } & $A$ 点 & 952 & 1587 & 608 & 9.6 & 5.5 & 4.0 & 10 & 7 \\
\hline & $B$ 点 & 84.8 & 1587 & 979 & 10.7 & 10.9 & 8.1 & 10 & 11 \\
\hline & $\mathrm{D}$ 点 & 1587 & 952 & 558 & 11.0 & 10.3 & 3.5 & 12 & 11 \\
\hline \multirow{3}{*}{$\mathrm{D}$ 型 } & $\mathrm{A}$ 点 & 643 & 1072 & 657 & 9.5 & 3.7 & 2.7 & 10 & 6 \\
\hline & $B$ 点 & 683 & 0 & 415 & 8.5 & 0 & 0 & 10 & 11 \\
\hline & $\mathrm{D}$ 点 & 1072 & 643 & 604 & 9.9 & 7.0 & 2.4 & 10 & 7 \\
\hline
\end{tabular}
の最大軸方向ひずみは $2.31 \%$ であった.

その後 $R=0.04,0.05,0.06 \mathrm{rad}$ を 2 回ずつ載荷し, 接合アング

\begin{tabular}{|c|c|c|c|c|c|c|c|c|c|c|c|c|}
\hline \multicolumn{11}{|c|}{ 耐力計算值 } & \multicolumn{2}{|c|}{ 最大荷重実験値 } \\
\hline & ダンパー & 柱 & 梁 & & エン & - & & & 合アン & & 寸今゙り發牛前 & 㝏䮥全休 \\
\hline & 降伏 & 降伏 & 降伏 & ${ }_{e} S_{c}$ & ${ }_{e} S_{b}$ & ${ }_{e} O_{c}$ & ${ }_{e} O_{b}$ & ${ }_{a} S_{c}$ & ${ }_{a} S_{b}$ & ${ }_{a} \mathrm{O}$ & 里无土朐 & 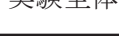 \\
\hline $\mathrm{S}$ 型 & 466 & 828 & 596 & 695 & 656 & 644 & 631 & 597 & 625 & 623 & 571 & 828 \\
\hline $\mathrm{D}$ 型 & 514 & 1833 & 595 & 793 & 787 & 664 & 849 & 1046 & $\pi$ & 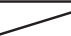 & & 732 \\
\hline
\end{tabular}

表 4 隅肉溶接の設計

表 5 方杖ダンパー接合構造試験体の耐力計算值と最大荷重の実験值（単位 $[\mathrm{kN}]$ ）

表中の值は各構造要素の耐力時の載荷荷重 $Q$ であり, $S$ は高力ボルト摩擦接合部のすべり耐力, $O$ は面外曲げ降伏耐力を示す. 各記号の添字 は $c$ が柱側, $b$ が梁側を示す. 
ルと梁の摩擦面ですべりが生じているものの概ね紡錘形の $Q / Q_{y}-R$ 関係が得られることを確認した. $R=0.06 \mathrm{rad}$ の載荷後は正側に単調 載荷を行った．接合アングルと梁フランジの高力ボルト摩擦接合部 を除くすべての接合部で設計時に期待される耐力を上回ってもす心゙ りや離間が生じておらず，設計の妥当性が確認された．最大変形時
の状況を写真 2 に示す．実験によるダンパーの最大軸方向ひずみは $14.4 \%$ であった。

層間変形角に占める各部材の変形角の割合を図 11 に示寸. $\theta_{b}$ は梁 の載荷点からダンパー取付位置までの变形角, $\theta_{c}$ は柱の支持点から 方杖ダンパーの取付位置までの変形角, $\theta_{d}$ はダンパー取付位置から

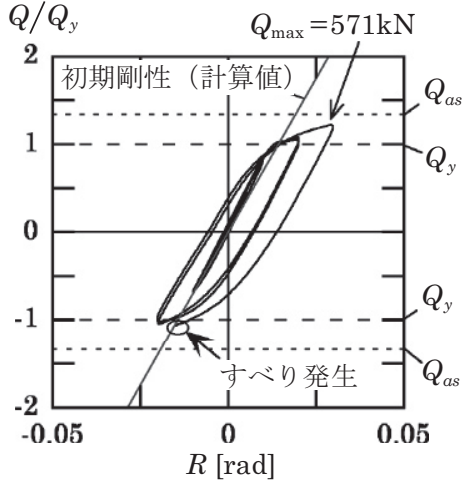

(a) すべり発生前

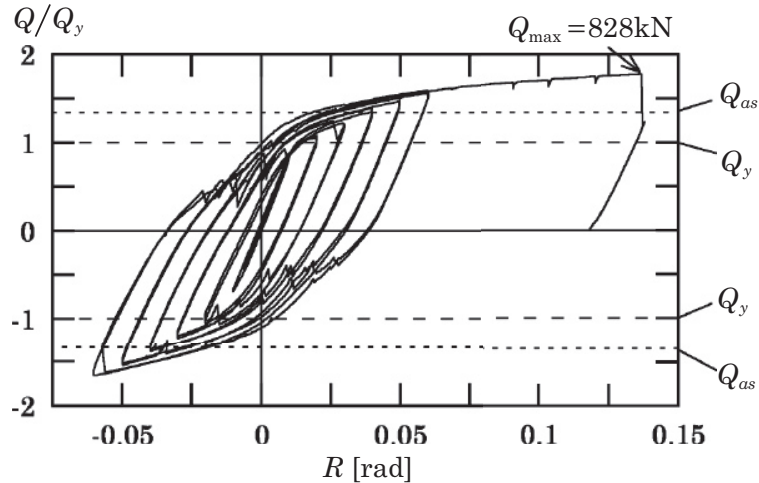

(b) 実験全体

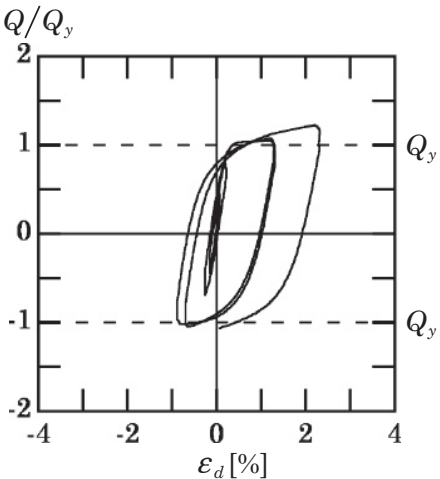

図 $10 \mathrm{~S}$ 型, $Q / Q_{y}-\varepsilon_{d}$ 関係

図 $9 \quad \mathrm{~S}$ 型， $Q / Q_{y}-R$ 関係

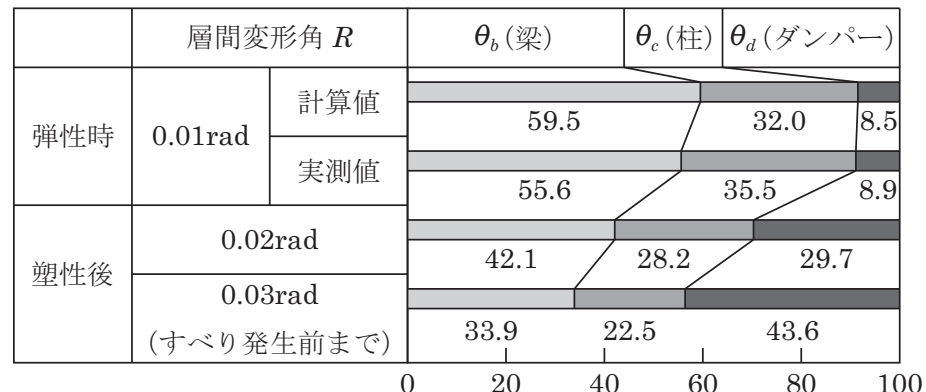

図 11 各部材の変形角が層間変形角に占める割合（S 型，単位 $[\%] ）$

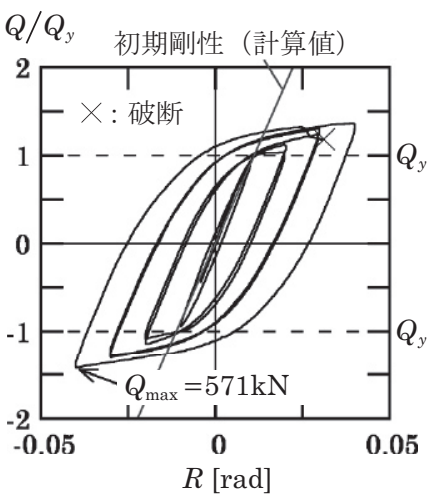

図 $12 \mathrm{D}$ 型, $Q / Q_{y}-R$ 関係

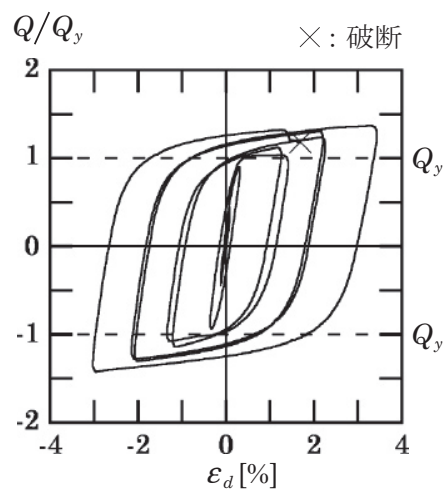

図 $13 \mathrm{D}$ 型, $Q / Q_{y}-\varepsilon_{d}$ 関係

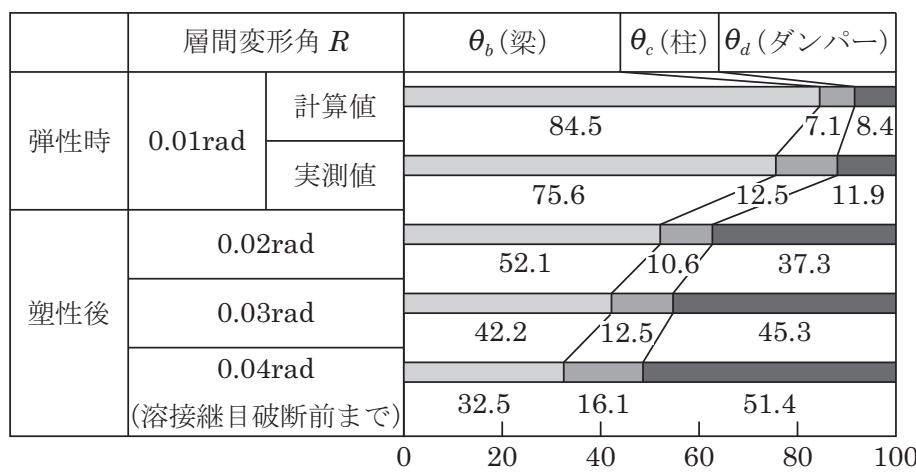

図 14 各部材の変形角が層間変形角に占める割合 $(\mathrm{D}$ 型，単位 [\%]）

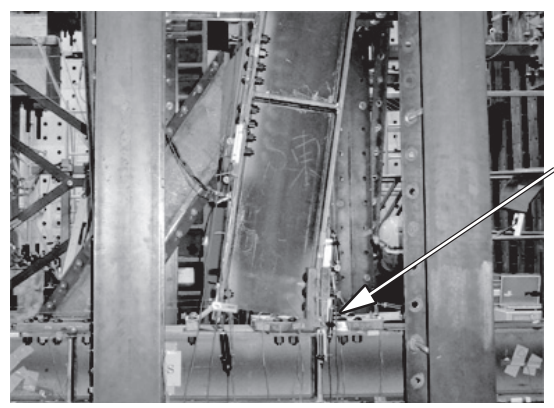

写真 $2 \mathrm{~S}$ 型, 最大変形時 $(R=0.136 \mathrm{rad})$
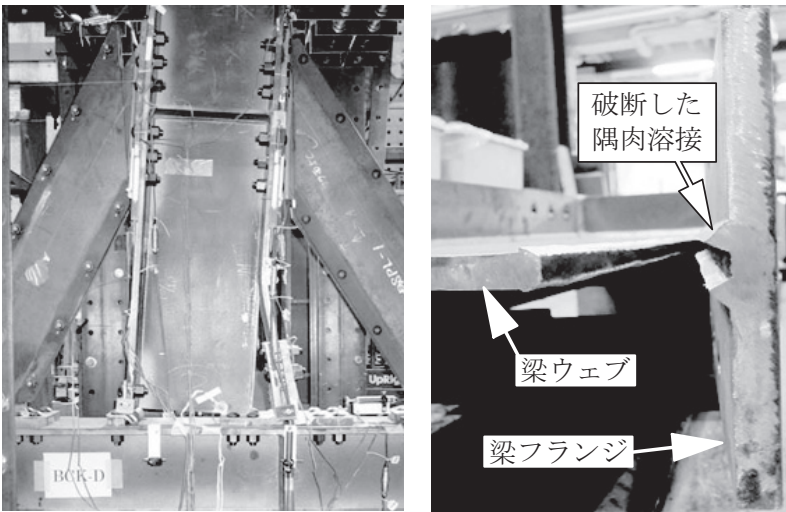

写真 $3 \mathrm{D}$ 型, 最大変形時 $(R=0.04 \mathrm{rad})$ の溶接継目破断の様子

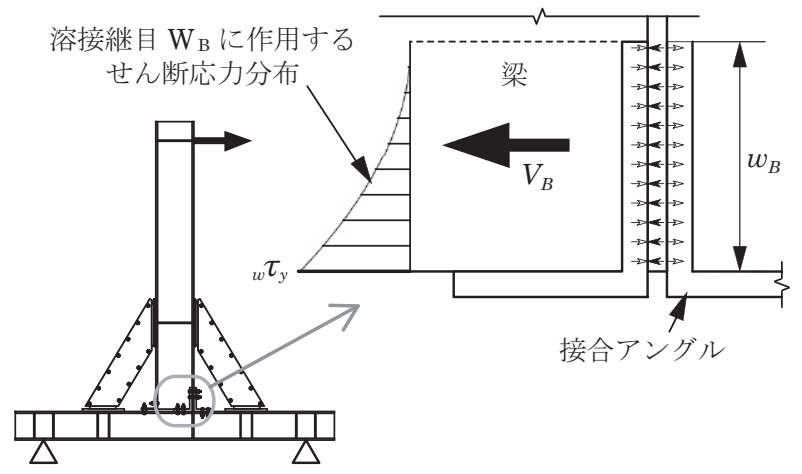

図 $15 \mathrm{~W}_{\mathrm{B}}$ の応力分布
アングルと 梁の摩擦面で すべりが発生 
梁と柱の接合部までの変形角を示す．図 11 より弾性時はほとんどの 変形は柱と梁であり, ダンパーの降伏後はダンパーが全体の変形に 占める割合が徐々に大きくなる（R=0.02 $\mathrm{rad} の と き \theta_{b}$ は $42.1 \%, \theta_{c}$ は $28.2 \%, \theta_{d}$ は $\left.29.7 \%\right)$.

\subsection{D型試験体結果}

図 12 に D 型試験体の $Q / Q_{y}-R$ 関係を, 図 13 に $Q / Q_{y}-\varepsilon_{d}$ 関係を 示す (溶接継目破断前まで). また表 5 に実験の最大荷重を示す.

図 12 より，初期剛性は図中に直線で示寸計算值 89.7[1/ rad] に対 して, 実験值は $103[1 / \mathrm{rad}]$ で $15 \%$ 高い， $Q_{y}$ に達した辺りから剛性 が低下し，柱梁が弾性のまま方杖ダンパーのみが塑性化し，層間変 形角 $R$ が 0.03rad まで接合部にす心゙り等は生じておらず，安定した 紡鍾形の挙動が確認できる. その後 $R=0.04 \mathrm{rad} の 1$ 回目の載荷中 $Q=679 \mathrm{kN}$ で, 梁端の接合アングル接合部における梁のウェブフィ レット部の隅肉溶接継目（以下 $\mathrm{W}_{\mathrm{B}}$ と称す）が破断した。 その他の 接合部は設計時に期待される耐力を上回っており, 設計の妥当性が 確認された．ダンパーの軸方向ひずみは接合アングルから遠い下フ ランジ側のダンパーの方が大きく, 溶接継目破断前のダンパーの最 大軸方向ひずみは $3.42 \%$ であった。

$\mathrm{S}$ 型と同様に層間変形角に占める各部材の変形角の割合を図 14 に 示す. 図 14 より弾性時はほとんどの変形は柱と梁であり, ダンパー の降伏後はダンパーが全体の変形に占める割合が徐々に大きくなる $\left(R=0.02 \mathrm{rad}\right.$ のとき $\theta_{b}$ は $52.1 \%, \theta_{c}$ は $10.6 \%, \theta_{d}$ は $\left.37.3 \%\right)$.

破断した $\mathrm{W}_{\mathrm{B}}$ の必要サイズは方杖ダンパー取付位置の設計条件で 決定したため，新たに梁端接合部の設計方法を検討した。 $\mathrm{W}_{\mathrm{B}}$ には図 15 に示寸梁のせん断力 $V_{B}$ が作用して接合アングルには曲げ変形が
生じるため, $\mathrm{W}_{\mathrm{B}}$ の応力分布は一様ではなく図 15 の放物線状になる と仮定する. せん断応力が最大となる梁端の溶接継目が前面隅肉溶 接の降伏せん断応力 ${ }_{w} \tau_{y}$ に達しないように設計する. 寸なわち設計用 せん断力 $V_{B}$ （ダンパーの軸力が $1.4_{d} N_{y}$ のときの值）に対して, $\mathrm{W}_{\mathrm{B}}$ の必要サイズ $s_{B}$ を次式で求める $\left(w_{B}\right.$ は梁端からのアングルの長さ).

$$
V_{B} \leq \frac{1}{3} \cdot 1.4_{w} \tau_{y} \cdot 2 \frac{s_{B}}{\sqrt{2}} w_{B}
$$

今回の試験体の $\mathrm{W}_{\mathrm{B}}$ の隅肉サイズ $s_{B}$ の設計值と実測值，および (3) 式より求められる必要サイズを表 6 に示す. 表 6 より, D 型試験体 の場合, $s_{B}$ の必要值は $15.9 \mathrm{~mm}$ 以上であるのに対し， $s_{B}$ の実寸は $10.1 \mathrm{~mm}$ だったため, 実験ではせん断降伏応力を超えることになる. 上式の ${ }_{w} \tau_{y}$ を ${ }_{w} \tau_{u}$ に置きかえて破断時の $V_{B}$ を求めると $687 \mathrm{kN}$ となり, 実験で破断した際の $V_{B}$ は $769 \mathrm{kN}$ でこれを上回るため破断したと考 えられる。

\section{4. 方杖ダンパー接合構造の試設計と地震応答性状}

\section{1 設計骨組と設計条件}

本章では，従来鋼の柱梁を用いた方杖ダンパー接合構造の試設計 に関する既往の研究と同じ設計条件下で，柱梁に高強度鋼を用いた 場合の試設計を行い, 鋼材重量と地震応答性状を比較することで, 3

表 $6 \mathrm{~W}_{\mathrm{B}}$ の隅肉サイズ $s_{B}$ の設計值と必要值（単位 $[\mathrm{mm}]$ ）

\begin{tabular}{|c|c|c|c|}
\hline \multirow{2}{*}{} & \multicolumn{2}{|c|}{ 試験体 } & \multirow{2}{*}{$\begin{array}{c}\text { (3) 式より得られる } \\
\text { 必要サイズ }\end{array}$} \\
\cline { 2 - 3 } & 設計值 & 実測值 & 9.7 \\
\hline $\mathrm{D}$ 型 & 12 & 13.1 & 15.9 \\
\hline
\end{tabular}

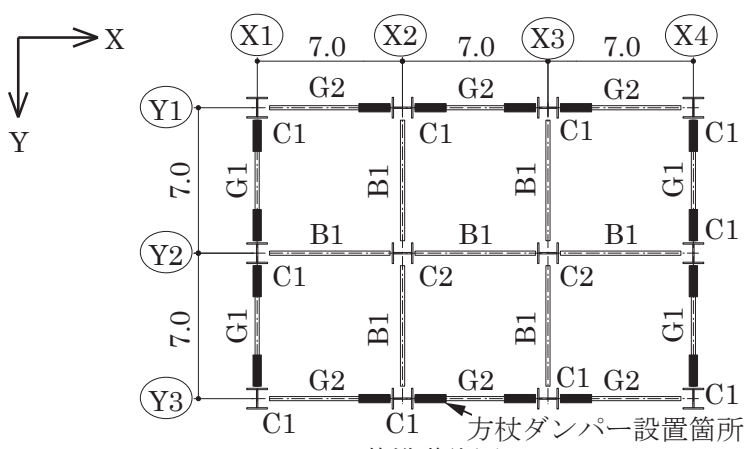

(a) 基準階伏図

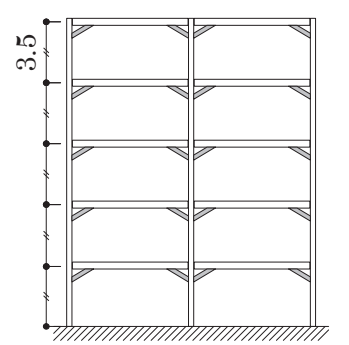

(b) X1，X4 構面軸組図

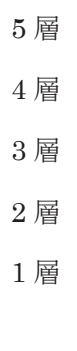

図 $16 \mathrm{~S}$ 型モデル骨組（5 層の場合，単位 $[\mathrm{m}]$ ）

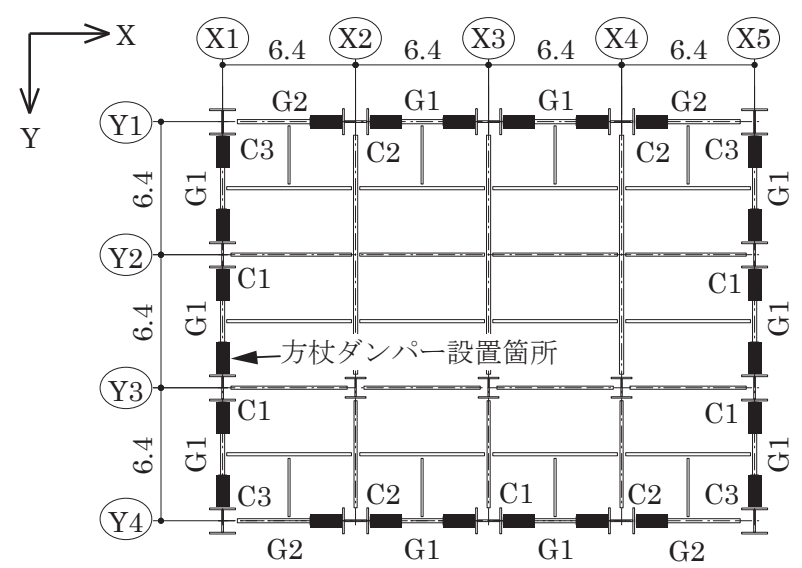

(a) 基準階伏図

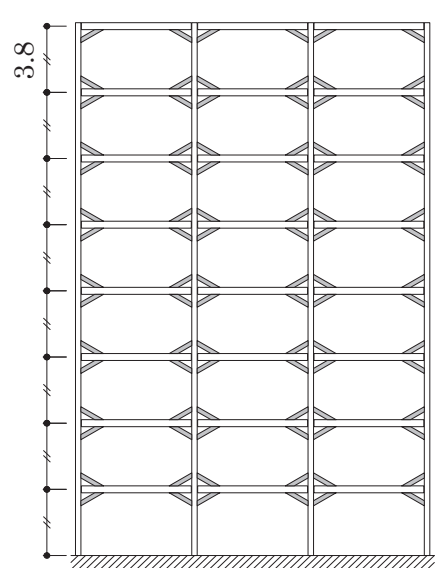

(b) X1，X5 構面軸組図

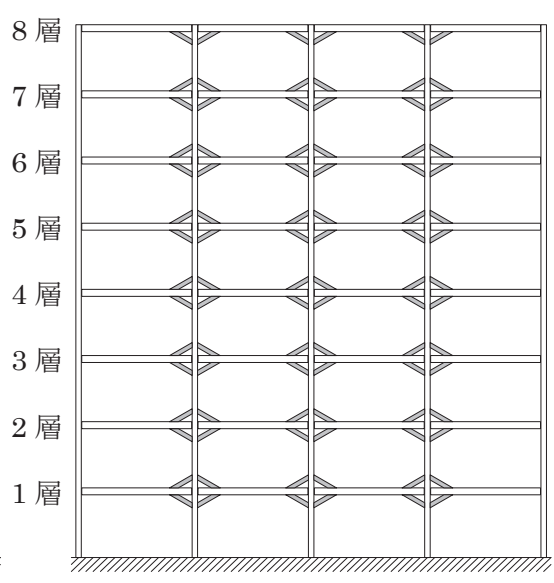

(c) Y1，Y4 構面軸組図

図 17 D 型モデル骨組（単位 $[\mathrm{m}] ）$ 
章で示した高強度鋼の柱梁と方杖ダンパーの接合構造の有用性を確 認する. 設計対象は文献 22) の $\mathrm{S}$ 型を用いた 5 層および 10 層骨組, 文献 23)の D 型を用いた 8 層骨組（最上層は $\mathrm{S}$ 型）の 2 種類の骨組 である， S 型，D型モデルの基準階伏図と軸組図をそれぞれ図 16 , 17 に示す．また設計条件を以下に示す.

(1) 方杖ダンパー芯材の鋼種は, $\mathrm{S}$ 型の場合低降伏点鋼（基準強度 $205 \mathrm{~N} / \mathrm{mm}^{2}$ ), D 型の場合 SN400B（基準強度 $235 \mathrm{~N} / \mathrm{mm}^{2}$ ）とし, $\mathrm{D}$ 型では標準ラインアップ 24) より選択する。 方杖ダンパーの寸法 は, 梁材軸方向長さ $l_{d}=1.0 \mathrm{~m}$, 柱材軸方向長さ $h_{d}=0.6 \mathrm{~m}$ とする.

(2) 1 次設計用地震荷重 $\left(C_{0}=0.2\right)$ に対して方杖ダンパーは弾性 で，層間変形角の制限值は $\mathrm{S}$ 型の場合 $1 / 200 \mathrm{rad} ， \mathrm{D}$ 型の場合 1/180rad とする.

(3) 保有水平耐力が 2 次設計用地震荷重 $\left(C_{0}=1.0, D_{S}=0.25\right)$ を上回 り, また保有水平耐力時に柱梁の応力は有効断面において降伏曲 げ耐力以下とする.

(4) $\mathrm{D}$ 型では方杖ダンパーが取り付けられる外周構面の柱梁だけに高 強度鋼を用い, それ以外の構面の柱や小梁に関しては文献 23) と
同じ従来鋼を選定する．S 型では全ての柱梁を高強度鋼で設計す る.

高強度鋼を用いる場合，耐力の条件から決まる断面では部材断面 が小さくなり，変形の制限によって断面が決まると考えられる，そ のため，(2)の層間変形角の制限值を除いて耐力だけで設計した結果， および層間変形角の制限值を文献 25) の上限である $1 / 120 \mathrm{rad}$ まで 緩和して設計した結果（D型のみ）を併せて示す．なお，解析には CLAP $^{26)}$ を用いた。

\section{2 設計結果}

設計によって得られた部材断面を表 7 〜表 13 に示す（S 型モデ ルの小梁 B1 は全て BH $-390 \times 160 \times 9 \times 12$ である)。また鋼材重 量を算出し，従来鋼の場合と比較した結果を図 18 に示す．同じ条 件で設計された従来鋼による角形鋼管柱と $\mathrm{H}$ 形鋼梁のラーメン構 造の鋼材重量も併記する．ただし， S 型は方杖ダンパーの詳細設計 を行っていないので, 柱・梁（小梁を含む）の重量のみを比較す る.また，ラーメン構造には継手添板とダイアフラムの重量を含 まない，方杖ダンパー接合構造の各骨組に設計用地震荷重を比例

表 7 S 型モデル 5 層骨組の部材断面（変形制限なし）

\begin{tabular}{|c|c|c|c|c|c|c|}
\hline \multirow{2}{*}{ 層 } & \multicolumn{2}{|c|}{ 柱 } & \multicolumn{2}{|c|}{ 大梁 } & \multicolumn{2}{|c|}{ 方杖ダンパー [mm] } \\
\hline & $\mathrm{C} 1$ & $\mathrm{C} 2$ & $\mathrm{X} 1, \mathrm{X} 4$ 構面 (G1) & Y1, Y3 構面（G2） & $\mathrm{X} 1, \mathrm{X} 4$ 構面 & Y1, Y3 構面 \\
\hline 5 & \multirow{3}{*}{$\mathrm{BH}-320 \times 280 \times 12 \times 16$} & \multirow{5}{*}{$\mathrm{BH}-180 \times 180 \times 9 \times 12$} & $\mathrm{BH}-200 \times 200 \times 9 \times 12$ & $\mathrm{BH}-210 \times 200 \times 9 \times 12$ & $16 \times 130$ & $16 \times 130$ \\
\hline 4 & & & $\mathrm{BH}-290 \times 200 \times 9 \times 12$ & $\mathrm{BH}-370 \times 200 \times 9 \times 12$ & $16 \times 190$ & $16 \times 240$ \\
\hline 3 & & & $\mathrm{BH}-350 \times 200 \times 9 \times 12$ & $\mathrm{BH}-410 \times 210 \times 12 \times 12$ & $19 \times 190$ & $19 \times 240$ \\
\hline 2 & \multirow{2}{*}{$\mathrm{BH}-320 \times 320 \times 12 \times 19$} & & $\mathrm{BH}-390 \times 200 \times 9 \times 12$ & $\mathrm{BH}-480 \times 210 \times 12 \times 12$ & $19 \times 220$ & $22 \times 240$ \\
\hline 1 & & & $\mathrm{BH}-400 \times 210 \times 12 \times 12$ & $\mathrm{BH}-480 \times 200 \times 12 \times 16$ & $19 \times 230$ & $22 \times 240$ \\
\hline
\end{tabular}

表 8 S 型モデル 5 層骨組の部材断面（変形制限 $1 / 200 \mathrm{rad}$ )

\begin{tabular}{|c|c|c|c|c|c|c|}
\hline \multirow{2}{*}{ 層 } & \multicolumn{2}{|c|}{ 柱 } & \multicolumn{2}{|c|}{ 大梁 } & \multicolumn{2}{|c|}{ 方杖ダンパー [mm] } \\
\hline & $\mathrm{C} 1$ & $\mathrm{C} 2$ & $\mathrm{X} 1, \mathrm{X} 4$ 構面 (G1) & Y1, Y3 構面 (G2) & $\mathrm{X} 1, \mathrm{X} 4$ 構面 & Y1, Y3 構面 \\
\hline 5 & \multirow{4}{*}{$\mathrm{BH}-400 \times 360 \times 16 \times 22$} & \multirow{4}{*}{$\mathrm{BH}-180 \times 180 \times 9 \times 12$} & $\mathrm{BH}-340 \times 200 \times 9 \times 12$ & $\mathrm{BH}-420 \times 210 \times 12 \times 12$ & $19 \times 120$ & $22 \times 150$ \\
\hline 4 & & & $\mathrm{BH}-510 \times 200 \times 12 \times 16$ & $\mathrm{BH}-580 \times 220 \times 16 \times 16$ & $22 \times 240$ & $25 \times 250$ \\
\hline 2 & & & $\mathrm{BH}-660 \times 230 \times 16 \times 16$ & $\mathrm{BH}-780 \times 240 \times 19 \times 19$ & $25 \times 250$ & $28 \times 230$ \\
\hline 1 & & & $\mathrm{BH}-520 \times 200 \times 12 \times 16$ & $\mathrm{BH}-680 \times 230 \times 16 \times 16$ & $25 \times 250$ & $28 \times 230$ \\
\hline
\end{tabular}

表 $9 \mathrm{~S}$ 型モデル 10 層骨組の部材断面（変形制限なし）

\begin{tabular}{|c|c|c|c|c|c|c|}
\hline \multirow{2}{*}{ 層 } & \multicolumn{2}{|c|}{ 柱 } & \multicolumn{2}{|c|}{ 大梁 } & \multicolumn{2}{|c|}{ 方杖ダンパー $[\mathrm{mm}]$} \\
\hline & $\mathrm{C} 1$ & $\mathrm{C} 2$ & $\mathrm{X} 1, \mathrm{X} 4$ 構面 (G1) & Y1, Y3 構面（G2） & $\mathrm{X} 1, \mathrm{X} 4$ 構面 & Y1, Y3 構面 \\
\hline 10 & \multirow{7}{*}{ BH $-340 \times 300 \times 12 \times 19$} & \multirow{7}{*}{$\mathrm{BH}-240 \times 200 \times 12 \times 16$} & $\mathrm{BH}-200 \times 200 \times 9 \times 12$ & $\mathrm{BH}-200 \times 200 \times 9 \times 12$ & $12 \times 130$ & $12 \times 140$ \\
\hline 9 & & & $\mathrm{BH}-220 \times 200 \times 9 \times 12$ & $\mathrm{BH}-300 \times 200 \times 9 \times 12$ & $16 \times 160$ & $12 \times 250$ \\
\hline 7 & & & $\mathrm{BH}-310 \times 200 \times 9 \times 12$ & $\mathrm{BH}-400 \times 210 \times 12 \times 12$ & $16 \times 230$ & $22 \times 190$ \\
\hline 6 & & & $\mathrm{BH}-340 \times 200 \times 9 \times 12$ & $\mathrm{BH}-420 \times 210 \times 12 \times 12$ & $19 \times 210$ & $22 \times 210$ \\
\hline 5 & & & $\mathrm{BH}-370 \times 200 \times 9 \times 12$ & $\mathrm{BH}-450 \times 210 \times 12 \times 12$ & $19 \times 230$ & $25 \times 200$ \\
\hline 4 & & & $\mathrm{BH}-390 \times 200 \times 9 \times 12$ & $\mathrm{BH}-480 \times 210 \times 12 \times 12$ & $19 \times 240$ & $22 \times 240$ \\
\hline 3 & & & $\mathrm{BH}-390 \times 200 \times 12 \times 12$ & $\mathrm{BH}-480 \times 200 \times 12 \times 16$ & $22 \times 220$ & $25 \times 230$ \\
\hline 2 & \multirow{2}{*}{$\mathrm{BH}-340 \times 340 \times 12 \times 19$} & \multirow{2}{*}{$\mathrm{BH}-240 \times 230 \times 12 \times 16$} & $\mathrm{BH}-390 \times 210 \times 12 \times 12$ & $\mathrm{BH}-480 \times 200 \times 12 \times 16$ & $22 \times 230$ & $25 \times 240$ \\
\hline 1 & & & $\mathrm{BH}-410 \times 210 \times 12 \times 12$ & $\mathrm{BH}-520 \times 200 \times 12 \times 16$ & $22 \times 230$ & $25 \times 240$ \\
\hline
\end{tabular}

表 $10 \mathrm{~S}$ 型モデル 10 層骨組の部材断面（変形制限 $1 / 200 \mathrm{rad}$ )

\begin{tabular}{|c|c|c|c|c|c|c|}
\hline \multirow{2}{*}{ 層 } & \multicolumn{2}{|c|}{ 柱 } & \multicolumn{2}{|c|}{ 大梁 } & \multicolumn{2}{|c|}{ 方杖ダンパー [mm] } \\
\hline & $\mathrm{C} 1$ & $\mathrm{C} 2$ & $\mathrm{X} 1, \mathrm{X} 4$ 構面 (G1) & Y1, Y3 構面（G2） & $\mathrm{X} 1, \mathrm{X} 4$ 構面 & Y1, Y3 構面 \\
\hline 10 & \multirow{5}{*}{$\mathrm{BH}-420 \times 380 \times 16 \times 22$} & \multirow{6}{*}{$\mathrm{BH}-240 \times 200 \times 12 \times 16$} & $\mathrm{BH}-330 \times 200 \times 9 \times 12$ & $\mathrm{BH}-420 \times 210 \times 12 \times 12$ & $12 \times 140$ & $12 \times 140$ \\
\hline 9 & & & $\mathrm{BH}-470 \times 210 \times 12 \times 12$ & $\mathrm{BH}-530 \times 200 \times 12 \times 19$ & $22 \times 180$ & $22 \times 220$ \\
\hline 7 & & & $\mathrm{BH}-530 \times 200 \times 12 \times 19$ & $\mathrm{BH}-670 \times 230 \times 16 \times 16$ & $25 \times 230$ & $25 \times 220$ \\
\hline 6 & & & $\mathrm{BH}-560 \times 220 \times 16 \times 16$ & $\mathrm{BH}-700 \times 210 \times 16 \times 22$ & $28 \times 240$ & $25 \times 240$ \\
\hline 5 & & & $\mathrm{BH}-590 \times 220 \times 16 \times 16$ & $\mathrm{BH}-730 \times 230 \times 19 \times 19$ & $28 \times 240$ & $28 \times 250$ \\
\hline 3 & $\mathrm{BH}-420 \times 390 \times 16 \times 22$ & & $\mathrm{BH}-640 \times 220 \times 16 \times 16$ & $\mathrm{BH}-770 \times 230 \times 19 \times 19$ & $28 \times 240$ & $28 \times 250$ \\
\hline 2 & \multirow{2}{*}{$\mathrm{BH}-420 \times 420 \times 16 \times 25$} & \multirow{2}{*}{$\mathrm{BH}-240 \times 230 \times 12 \times 16$} & $\mathrm{BH}-640 \times 220 \times 16 \times 16$ & $\mathrm{BH}-800 \times 240 \times 19 \times 19$ & $28 \times 240$ & $28 \times 250$ \\
\hline 1 & & & $\mathrm{BH}-600 \times 220 \times 16 \times 16$ & $\mathrm{BH}-720 \times 230 \times 19 \times 19$ & $28 \times 240$ & $28 \times 250$ \\
\hline
\end{tabular}


表 11 D 型モデル 8 層骨組の部材断面（変形制限なし）

\begin{tabular}{|c|c|c|c|c|c|c|}
\hline \multirow{2}{*}{ 層 } & \multicolumn{2}{|c|}{ 柱 } & \multicolumn{2}{|c|}{ 大梁 } & \multicolumn{2}{|c|}{ 方杖ダンパー } \\
\hline & $\mathrm{C} 1 \cdot \mathrm{C} 2$ & C3 & G1 & G2 & No. & 板厚 $\times$ 幅 $[\mathrm{mm}]$ \\
\hline 8 & \multirow{2}{*}{$\mathrm{BH}-350 \times 250 \times 12 \# 19$} & \multirow{4}{*}{$\mathrm{BH}-350 \times 250 \times 12 \times 16$} & $\mathrm{BH}-200 \times 200 \times 9 \times 12$ & $\mathrm{BH}-200 \times 200 \times 9 \times 16$ & 2 & $16 \times 120$ \\
\hline 7 & & & $\mathrm{BH}-390 \times 200 \times 9 \times 12$ & $\mathrm{BH}-390 \times 200 \times 9 \times 16$ & 4 & $16 \times 160$ \\
\hline 6 & \multirow{2}{*}{$\mathrm{BH}-350 \times 300 \times 12 \times 19$} & & $\mathrm{BH}-500 \times 200 \times 12 \times 12$ & $\mathrm{BH}-500 \times 200 \times 12 \times 12$ & 6 & $19 \times 180$ \\
\hline 5 & & & \multirow{5}{*}{$\mathrm{BH}-680 \times 200 \times 16 \times 12$} & \multirow{3}{*}{$\mathrm{BH}-680 \times 200 \times 16 \times 12$} & 8 & $19 \times 225$ \\
\hline 4 & \multirow{2}{*}{$\mathrm{BH}-350 \times 300 \times 12 \times 25$} & $\mathrm{BH}-350 \times 250 \times 12 \times 19$ & & & & \multirow{2}{*}{$22 \times 225$} \\
\hline 3 & & $\mathrm{BH}-350 \times 250 \times 12 \times 22$ & & & 9 & \\
\hline 2 & $\mathrm{BH}-350 \times 300 \times 12 \times 28$ & $\mathrm{BH}-350 \times 250 \times 12 \times 25$ & & \multirow{2}{*}{$\mathrm{BH}-680 \times 200 \times 16 \times 16$} & \multirow{2}{*}{10} & \multirow{2}{*}{$22 \times 255$} \\
\hline 1 & $\mathrm{BH}-350 \times 350 \times 12 \times 32$ & $\mathrm{BH}-350 \times 250 \times 12 \times 32$ & & & & \\
\hline
\end{tabular}

表 12 D 型モデル 8 層骨組の部材断面（変形制限 1/120rad）

\begin{tabular}{|c|c|c|c|c|c|c|}
\hline \multirow{2}{*}{ 層 } & \multicolumn{2}{|c|}{ 柱 } & \multicolumn{2}{|c|}{ 大梁 } & \multicolumn{2}{|c|}{ 方杖ダンパー } \\
\hline & $\mathrm{C} 1 \cdot \mathrm{C} 2$ & C3 & G1 & G2 & No. & 板厚 $\times$ 幅 $[\mathrm{mm}]$ \\
\hline 8 & \multirow{4}{*}{$\mathrm{BH}-400 \times 350 \times 16 \times 22$} & \multirow{2}{*}{$\mathrm{BH}-360 \times 250 \times 12 \times 16$} & $\mathrm{BH}-300 \times 200 \times 9 \times 12$ & $\mathrm{BH}-300 \times 200 \times 9 \times 12$ & 4 & $16 \times 160$ \\
\hline 7 & & & \multirow{2}{*}{$\mathrm{BH}-520 \times 200 \times 12 \times 19$} & \multirow{2}{*}{$\mathrm{BH}-520 \times 200 \times 12 \times 19$} & 6 & $19 \times 180$ \\
\hline 6 & & \multirow{2}{*}{$\mathrm{BH}-360 \times 300 \times 12 \times 19$} & & & 7 & $19 \times 200$ \\
\hline 5 & & & \multirow{2}{*}{$\mathrm{BH}-680 \times 200 \times 16 \times 16$} & \multirow{2}{*}{$\mathrm{BH}-680 \times 200 \times 16 \times 16$} & 8 & $19 \times 225$ \\
\hline 4 & \multirow{3}{*}{$\mathrm{BH}-400 \times 350 \times 16 \times 25$} & \multirow{3}{*}{$\mathrm{BH}-360 \times 300 \times 12 \times 22$} & & & \multirow{2}{*}{9} & \multirow{2}{*}{$22 \times 225$} \\
\hline 3 & & & $\mathrm{BH}-680 \times 250 \times 16 \times 19$ & $\mathrm{BH}-680 \times 250 \times 16 \times 19$ & & \\
\hline 2 & & & \multirow{2}{*}{$\mathrm{BH}-680 \times 300 \times 16 \times 19$} & \multirow{2}{*}{$\mathrm{BH}-680 \times 300 \times 16 \times 19$} & \multirow[t]{2}{*}{10} & \multirow[t]{2}{*}{$22 \times 255$} \\
\hline 1 & $\mathrm{BH}-400 \times 400 \times 16 \times 32$ & $\mathrm{BH}-360 \times 300 \times 12 \times 32$ & & & & \\
\hline
\end{tabular}

表 13 D 型モデル 8 層骨組の部材断面（変形制限 1/180rad）

\begin{tabular}{|c|c|c|c|c|c|c|}
\hline \multirow{2}{*}{ 層 } & \multicolumn{2}{|c|}{ 柱 } & \multicolumn{2}{|c|}{ 大梁 } & \multicolumn{2}{|c|}{ 方杖ダンパー } \\
\hline & $\mathrm{C} 1 \cdot \mathrm{C} 2$ & C3 & G1 & G2 & No. & 板厚 $\times$ 幅 $[\mathrm{mm}]$ \\
\hline 8 & \multirow{2}{*}{$\mathrm{BH}-450 \times 350 \times 16 \times 22$} & \multirow{2}{*}{$\mathrm{BH}-400 \times 300 \times 16 \times 19$} & $\mathrm{BH}-400 \times 200 \times 9 \times 16$ & $\mathrm{BH}-400 \times 200 \times 9 \times 16$ & 5 & $16 \times 180$ \\
\hline 7 & & & $\mathrm{BH}-500 \times 250 \times 16 \times 19$ & $\mathrm{BH}-500 \times 250 \times 16 \times 19$ & 7 & $19 \times 200$ \\
\hline 6 & \multirow{3}{*}{$\mathrm{BH}-450 \times 400 \times 16 \times 25$} & \multirow{3}{*}{$\mathrm{BH}-400 \times 300 \times 16 \times 25$} & $\mathrm{BH}-680 \times 250 \times 16 \times 19$ & $\mathrm{BH}-680 \times 250 \times 16 \times 19$ & \multirow{2}{*}{8} & \multirow{2}{*}{$19 \times 225$} \\
\hline 5 & & & $\mathrm{BH}-680 \times 250 \times 19 \times 19$ & $\mathrm{BH}-680 \times 250 \times 19 \times 19$ & & \\
\hline $\begin{array}{l}4 \\
3\end{array}$ & & & $\mathrm{BH}-810 \times 250 \times 19 \times 19$ & $\mathrm{BH}-810 \times 250 \times 19 \times 19$ & 9 & $22 \times 225$ \\
\hline 2 & $\mathrm{BH}-450 \times 400 \times 16 \times 28$ & $\mathrm{BH}-400 \times 300 \times 16 \times 28$ & \multirow{2}{*}{$\mathrm{BH}-810 \times 300 \times 19 \times 22$} & \multirow{2}{*}{$\mathrm{BH}-810 \times 300 \times 19 \times 22$} & \multirow{2}{*}{10} & \multirow{2}{*}{$22 \times 255$} \\
\hline 1 & $\mathrm{BH}-450 \times 450 \times 16 \times 32$ & $\mathrm{BH}-400 \times 400 \times 16 \times 28$ & & & & \\
\hline
\end{tabular}

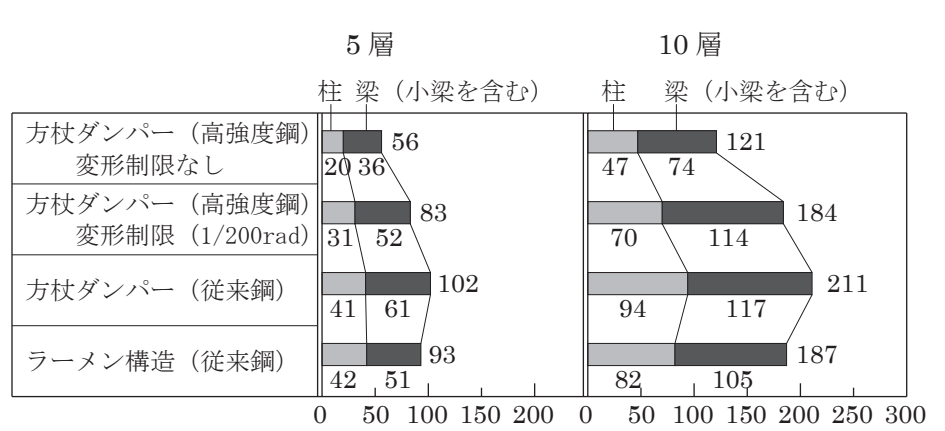

(a) $\mathrm{S}$ 型モデル

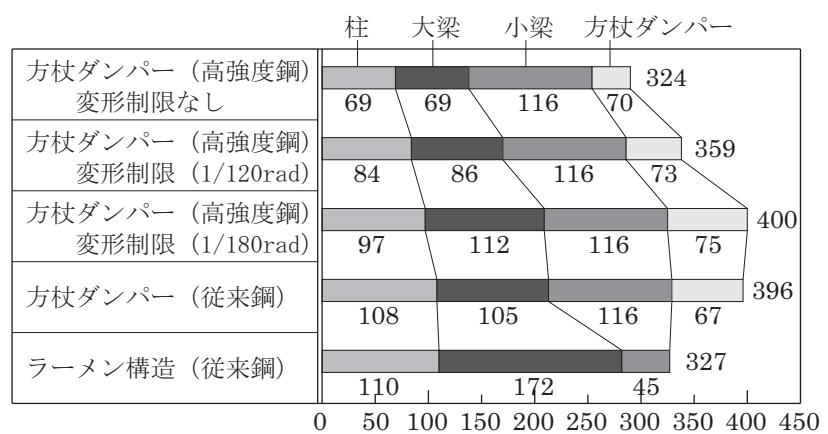

(b) $\mathrm{D}$ 型モデル

図 18 鋼材重量の比較 [ton]

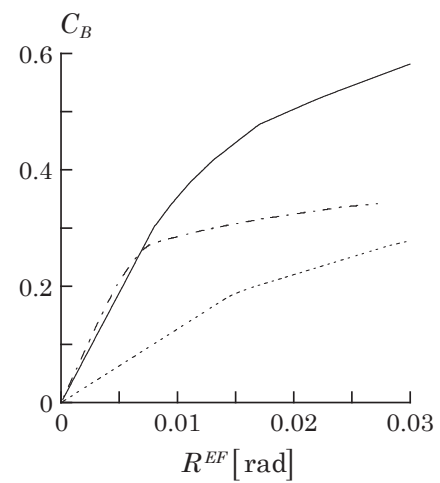

(a) $\mathrm{S}$ 型モデル 5 層（X 方向）

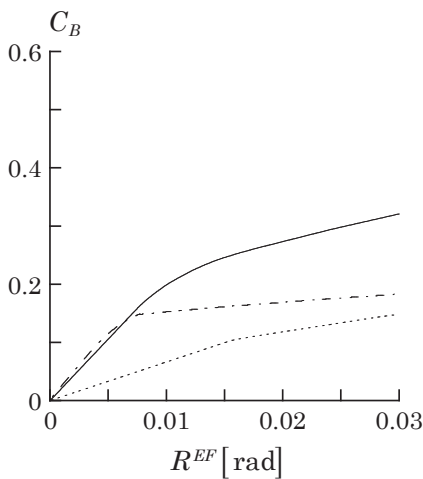

(b) $\mathrm{S}$ 型モデル 10 層（X 方向）

図19 各骨組の転倒モーメン

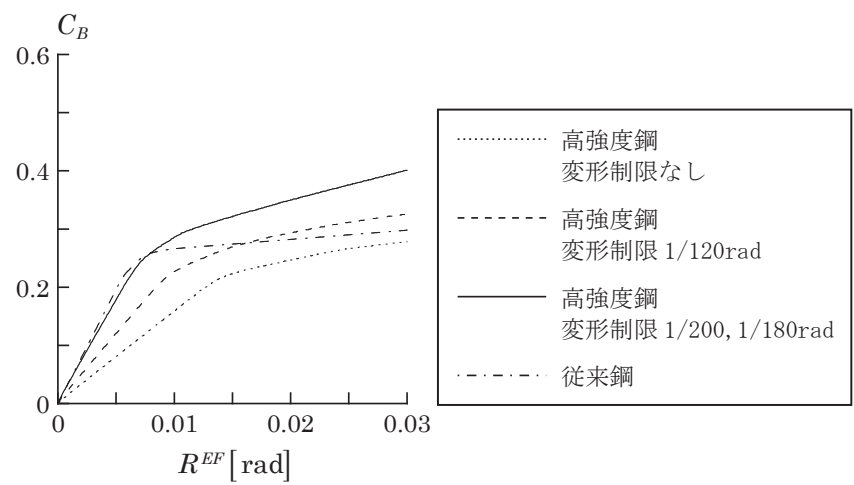

(c) $\mathrm{D}$ 型モデル 8 層 ( $\mathrm{X}$ 方向 $)$

と有効構造回転角の関係 
表 14 各骨組の 1 次固有周期 [s]

\begin{tabular}{|c|c|c|c|c|c|c|c|}
\hline \multirow{2}{*}{\multicolumn{2}{|c|}{\begin{tabular}{|ll} 
鋼 & 種 \\
\end{tabular}}} & \multicolumn{2}{|c|}{$\mathrm{S}$ 型 5 層 } & \multicolumn{2}{|c|}{$\mathrm{S}$ 型 10 層 } & \multicolumn{2}{|c|}{$\mathrm{D}$ 型 8 層 } \\
\hline & & $\mathrm{X}$ & $\mathrm{Y}$ & $\mathrm{X}$ & $\mathrm{Y}$ & $\mathrm{X}$ & $\mathrm{Y}$ \\
\hline \multirow{3}{*}{$\begin{array}{l}\text { 高強 } \\
\text { 度鋼 }\end{array}$} & なし & 1.80 & 1.77 & 3.40 & 3.43 & 2.08 & 1.90 \\
\hline & 1/120rad & - & $\begin{array}{cccc}- & \\
-\end{array}$ & - & $\begin{array}{cccc}- & \\
-\end{array}$ & 1.72 & 1.61 \\
\hline & $1 / 200,1 / 180 \mathrm{rad}$ & 1.05 & 1.05 & 1.91 & 1.91 & 1.41 & 1.32 \\
\hline \multicolumn{2}{|c|}{ 送来鋼 } & 0.89 & 0.96 & 1.66 & 1.83 & 1.35 & 1.32 \\
\hline
\end{tabular}

載荷したときのベースシヤ係数 $C_{B}$ と有効構造回転角 $R^{E F}[\mathrm{rad}]$ の 関係を図 19 に示す. また各骨組の 1 次固有周期を表 14 に示す.

$\mathrm{S}$ 型の場合, 高強度鋼柱梁と方杖ダンパー接合構造の柱梁の鋼材 重量は従来鋼による方杖ダンパー構造と比べ, 層間変形角を制限し ない場合 5 層骨組で $45 \%, 10$ 層骨組で $43 \%$ 減少し, 制限をした 場合 5 層で $19 \%$ ， 10 層で $13 \%$ 減少する結果となった，これは，従 来鋼による方杖ダンパー構造では, 保有水平耐力時に弾性を保つ条 件（設計条件(3)）によって部材断面が決定している ${ }^{22}$ ことに起因し ている．D型の場合，高強度鋼柱梁と方杖ダンパー接合構造の全鋼
表 15 入力地震波

\begin{tabular}{|c|c|c|c|c|}
\hline \multirow{2}{*}{ 地震波 } & \multirow{2}{*}{$\begin{array}{c}\text { 最大速度 } \\
{[\mathrm{m} / \mathrm{s}]}\end{array}$} & $\begin{array}{c}\text { 最大加速度 } \\
{\left[\mathrm{m} / \mathrm{s}^{2}\right]}\end{array}$ & \multicolumn{2}{|c|}{ 継続時間 [sec] } \\
\cline { 4 - 5 } & $\mathrm{S}$ 型 & $\mathrm{D}$ 型 \\
\hline El Centro NS 1940 & 0.500 & 5.11 & 30 & 50 \\
\hline Taft EW 1952 & 0.500 & 4.97 & 40 & 50 \\
\hline Hachinohe NS 1968 & 0.500 & 3.34 & 40 & 50 \\
\hline BCJ L2 & 0.574 & 3.56 & 120 & 120 \\
\hline
\end{tabular}

材重量は従来鋼による方杖ダンパー接合構造と比べ，層間変形角を 制限しない場合で $18 \%$ ，制限を $1 / 120 \mathrm{rad}$ に緩和した場合で $9 \%$ 減少 するが，従来鋼と同等の変形制限を課した場合には鋼材重量がほぼ 同等となることがわかった。

\section{3 地震応答解析}

各骨組について, 表 15 の入力地震波に対する地震応答解析を行っ た.ここでは S 型モデルのX 方向に El Centro NS を入力したとき の結果と, D 型 8 層モデルの X 方向に BCJ L2 を入力したときの結 果について示す. なお, $\mathrm{Y}$ 方向の応答や他の入力地震動に対する応

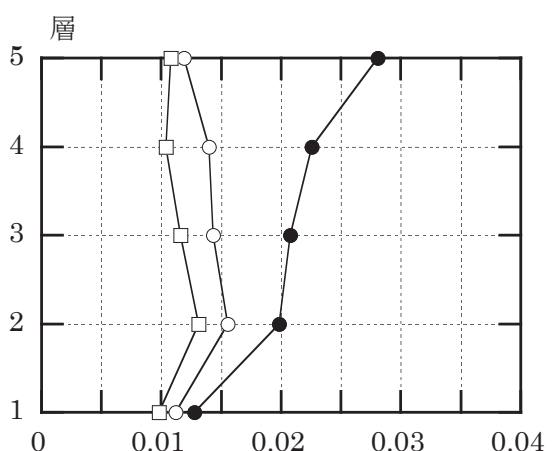

(a) 層間変形角 $[\mathrm{rad}]$

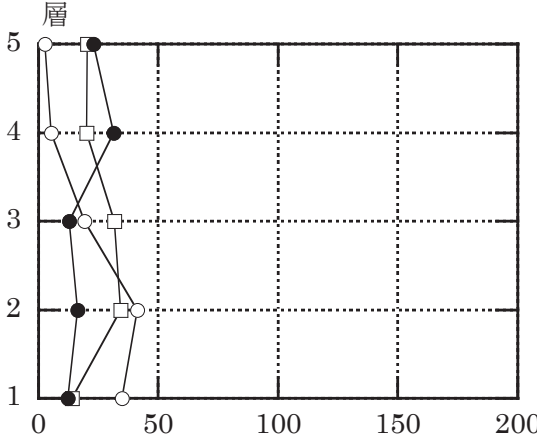

(b) 方杖ダンパーの累積塑性変形倍率

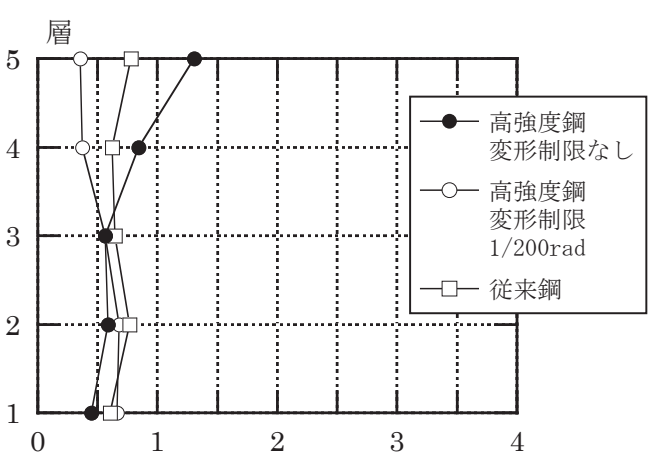

(c) 方杖ダンパーのひずみ [\%]

図 $20 \mathrm{~S}$ 型モデル 5 層骨組（X力方）の最大応答（El Centro NS）

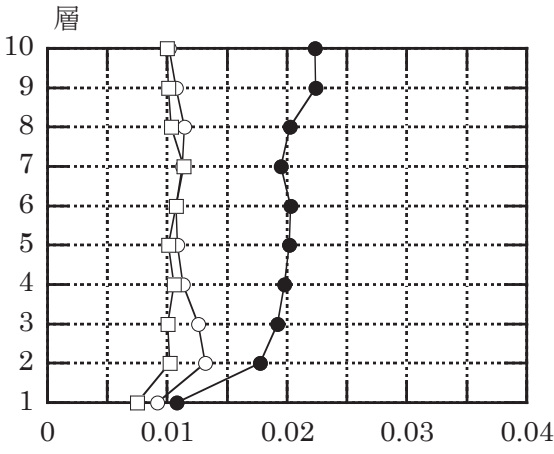

(a) 層間変形角 $[\mathrm{rad}]$

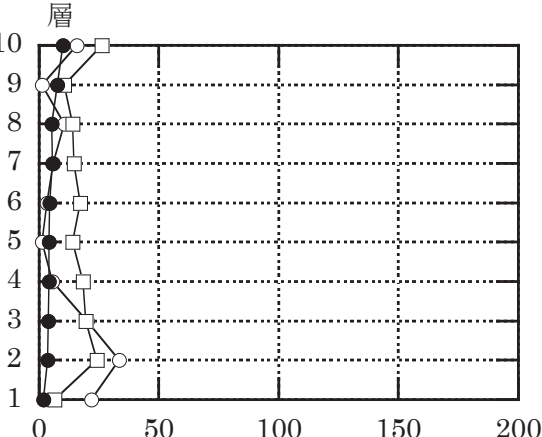

(b) 方杖ダンパーの累積塑性変形倍率

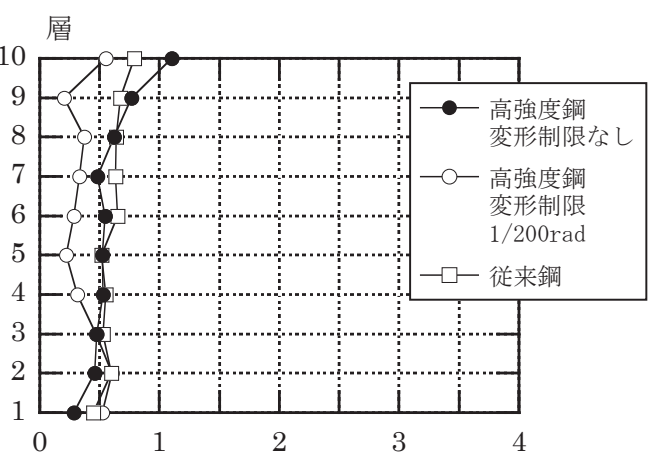

(c) 方杖ダンパーのひずみ [\%]

図 $21 \mathrm{~S}$ 型モデル 10 層骨組（X 方向）の最大応答（El Centro NS）

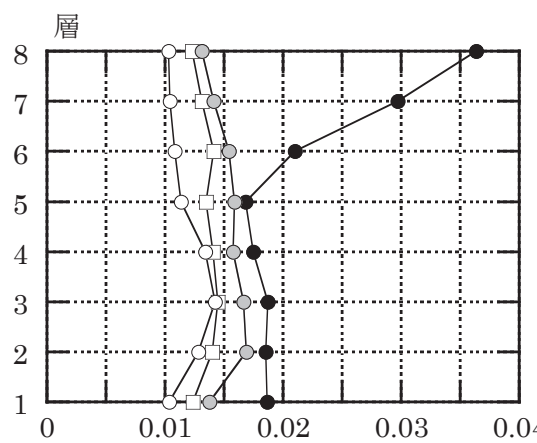

(a) 層間変形角 $[\mathrm{rad}]$

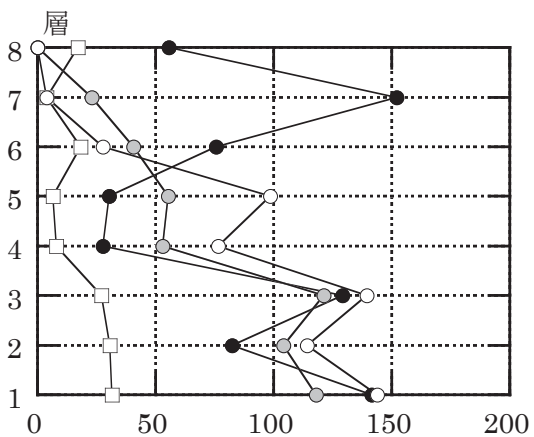

(b) 方杖ダンパーの累積塑性変形倍率

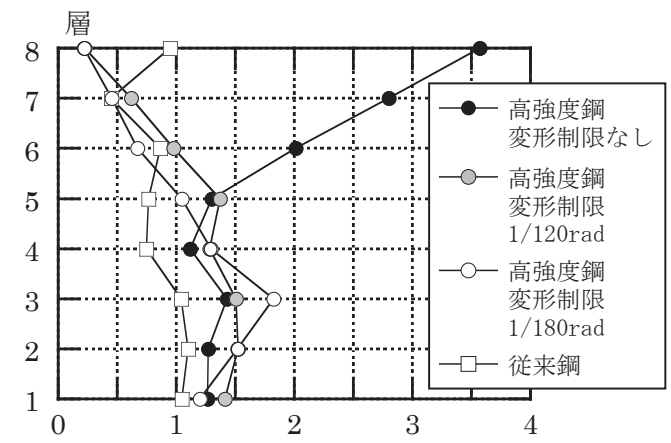

(c) 方杖ダンパーのひずみ [\%]

図 22 D 型モデル 8 層骨組 (X 方向) の最大応答 (BCJ) 
答でも同様の傾向が得られた.

従来鋼と高強度鋼の両方の骨組に関して，最大層間変形角，各層 に配置された方杖ダンパーの累積塑性変形倍率の最大值, 最大ひず みの值を図 20 ( $\mathrm{S}$ 型モデル，5 層)，図 21（ $\mathrm{S}$ 型モデル，10 層), 図 22 (D 型モデル，8 層）に示す. 図 20 ～22 より柱梁を高強度鋼で 設計した骨組の各種応答值に関して, 層間変形角は最大で変形制限

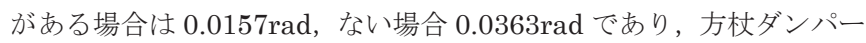
の累積塑性変形倍率は最大で変形制限がある場合は 143 , ない場合 152 であり, 方杖ダンパーの芯材のひずみは最大で変形制限がある 場合は $1.83 \%$ ，ない場合 $3.57 \%$ である.

図 $20 \sim 22$ より，変形制限を課した場合は $\mathrm{S}$ 型，D型ともに応答 に大きな差は見られなかった。また変形制限を課さない場合，3 章で 示した実験結果より接合部に多少のすべりの可能性があるが，破断 などは生じず比較的安定した履歴を得られる範囲にあり, 方杖ダン パーの応答值はダンパーの保有性能 ${ }^{24)}$ （最大ひずみ $4 \%$, 累積塑性変 形倍率 2300 以上）と比較しても十分小さい值である。一方，図 22

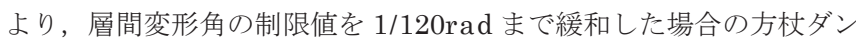
パーの応答は，緩和しない場合と比べてほとんど差が見られないこ とがわかる，以上より，高強度鋼の利用の観点から，骨組の層間変 形角制限を文献 25) のただし書きの範囲で緩和して設計することが 有効であると考えられる.

\section{5. まとめ}

アンダーマッチング溶接（G59J）による高強度鋼（H-SA700B） 組立部材を柱梁に使用した方杖ダンパー接合構造に関して実験と試 設計を行い，以下の点を明らかにした。

[1] 部分架構実験から大地震時に想定される最大層間変形角 $0.02 \mathrm{rad}$ まで柱梁および接合部は弾性のまま方杖ダンパーのみが塑性化し, 安定した履歴挙動が得られた。

[2] 梁端の接合アングルとの接合部における梁フランジ - ウェブ間の 溶接継目は局所的に大きな応力が作用し，実験で破断に至った。こ の破断を防止するための溶接継目の設計式（(3) 式）を提案した。

[3] 方杖ダンパー接合構造の試設計の結果, 高強度鋼を用いることで 従来鋼の場合と比べて，柱・梁の鋼材重量を低減することができる.

[4] 上記 [3] の試設計骨組に対する地震応答解析の結果，層間変形角 の制限を課した場合，高強度鋼による方杖ダンパー接合構造の応答 性状は従来鋼で設計した場合と比べて大差がない結果となった。ま た，層間変形角の制限值を文献 25)のただし書きの上限值まで緩和 して設計した場合でも，方杖ダンパーの応答はほとんど増大せず, 骨組の層間変形角制限を緩和して設計することが高強度鋼の利用の 観点からは有効であると考えられる。

\section{参考文献}

1) 日本鉄鋼連盟，日本鋼構造協会 : 平成 19 年度「革新的構造材料を用いた 新構造システム建築物研究開発」報告書, 2008.3.

2) 中井政義，中村豊，前田祥三，田中勉，浅井英克，鈴木庸介：高強度鋼を 用いた巨大地震に対する主架構無損傷設計法の提案, 日本建築学会構造系 論文集，第 76 巻，第 666 号，pp.1443-1451， 2011.8.

3) 金子貴司, 田中直樹，竹中啓之，佐々木聡 : 超高強度鋼を用いた柱梁接合 部実験（その 2 鋼管柱 $\mathrm{H}$ 形梁接合部実験), 日本建築学会大会学術講演 梗概集， C-1 構造 III，pp.757-758，2007.9.

4) 鈴井康正, 田中直樹, 竹中啓之, 佐々木聡 : 超高強度鋼を用いた柱梁接合 部実験（その 4 : ボックス柱 $-\mathrm{H}$ 形梁接合部実験)，日本建築学会大会学術
講演梗概集， C-1 構造 III，pp.1009-1010，2008.9.

5) 田中直樹，金子貴司，鈴井康正，竹中啓之，佐々木聡：超高強度鋼を用い た柱梁接合部実験 (その $5: \mathrm{H}$ 形柱 $-\mathrm{H}$ 形梁接合部実験), 日本建築学会 大会学術講演梗概集， C-1 構造 III，pp.1011-1012，2008.9。

6) 鈴井康正，田中直樹，竹中啓之，佐々木聡 : 超高強度鋼を用いた柱梁接合 部実験（その 7 : ボックス柱 $-\mathrm{H}$ 形梁接合部実験 1 ), 日本建築学会大会学 術講演梗概集， C-1 構造 III，pp.1039-1040，2009.8.

7) 田中直樹, 鈴井康正, 竹中啓之, 佐々木聡 : 超高強度鋼を用いた柱梁接合 部実験（その 8 : ボックス柱 $-\mathrm{H}$ 形梁接合部実験 2 ), 日本建築学会大会学 術講演梗概集， C-1 構造 III，pp.1041-1042，2009.8.

8) 田中直樹, 大塚克己, 清川貴世, 前田祥三 : $800 \mathrm{~N} / \mathrm{mm}^{2}$ 級超高強度鋼材を 用いたクロス $\mathrm{H}$ 形柱 $-\mathrm{H}$ 形梁高力ボルト接合部の弾塑性性状，日本鋼構造 協会鋼構造論文集，第 17 巻，第 65 号，pp.27-42，2010.3.

9) 竹内徹，大山翔也，石原直：制振部材を付加した高強度鋼架構の繰返し変 形性能 - 制振部材を付加した高強度鋼架構の而震性能 その $1-$, 日本建 築学会構造系論文集, 第 75 巻, 第 655 号, pp.1671-1679, 2010.9.

10) 木村祥裕，篠崎真一，石原直：高強度鋼ダイアフラムレス型柱梁部分架構 の損傷過程の解明と力学性能評価, 日本建築学会構造系論文集, 第 75 巻, 第 658 号，pp.2221-2230，2010.12

11) 佐藤篤司，木村慧，吹田啓一郎，井上一朗：建築構造用高強度鋼材 H-SA700A を用いた柱梁材を弾性に留める乾式接合法の開発，日本建築 学会構造系論文集，第 74 巻，第 646 号, pp.2355-2363，2009.12.

12) 玉井宏章, 松尾彰, 山西史朗, 高松隆夫: 建築構造用高強度鋼材 H-SA700A を用いた乾式組立材の弾性横座屈耐力評価式に関する一考察, 日本建築学会構造系論文集，第 76 巻，第 659 号，pp.157-165，2011.1.

13) 玉井宏章, 山西史朗, 高松隆夫, 松尾彰: 建築構造用高強度鋼材 H-SA700A を用いた乾式組立材の横座屈性状に関する実験的研究，日本 建築学会構造系論文集, 第 76 巻, 第 660 号, pp.407-415, 2011.2 .

14) 津田惠吾, 城戸将江, 河野昭彦: 建築構造用高強度鋼材 H-SA700 を用 いた柱材の設計式，日本建築学会構造系論文集，第 76 巻，第 670 号, pp.2163-2171, 2011.12.

15) 新才直紀，吹田啓一郎，佐藤篤司：アンダーマッチング溶接による高強度 鋼組立部材の性能評価実験，日本鋼構造協会鋼構造年次論文報告集，第 18 巻, pp.237-244, 2010.11 .

16) 吹田啓一郎、新才直紀 : アンダーマッチング溶接による高強度鋼組立柱 と従来鋼梁接合部の性能評価実験，構造工学論文集，Vol.58B，pp.375383, 2012.3.

17) 吹田啓一郎, 井上一朗, 竹内一郎, 宇野暢芳:座屈拘束された方杖ダンパー による柱梁高力ボルト接合構造の力学挙動, 日本建築学会構造系論文集, 第 571 号, pp.153-160，2003.9.

18）日本鉄鋼連盟 高性能鋼利用技術小委員会：建築構造用高性能 $590 \mathrm{~N} / \mathrm{mm}^{2}$ （SA440）設計・施工指針，2004.8

19) 聲高裕治, 安藤正和, 百野泰樹, 吹田啓一郎, 井上一朗 : 方杖ダンパーを 用いた柱梁高力ボルト接合構造の実大骨組実験，日本建築学会構造系論文 集, 第 595 号, pp.109-116, 2005.9.

20) 百野泰樹, 聲高裕治, 井上一朗, 諸岡繁洋 : 方杖ダンパーの座屈拘束設 計と性能確認実験，日本鋼構造協会鋼構造論文集，第 12 巻，第 45 号, pp.233-241, 2005.3.

21) 阪井宏行，聲高裕治，吹田啓一郎，井上一朗：方杖ダンパー接合構造にお ける梁および柱のスチフナの設計, 日本建築学会近畿支部研究報告集，第 50 号，構造系，2010.6.

22) 張シシュン，井上一朗，聲高裕治，百野泰樹：方杖ダンパーを用いた柱梁 高力ボルト接合骨組の設計と地震応答, 日本鋼構造協会鋼構造論文集，第 11 号，第 42 号，pp.63-73，2004.6.

23) 貝谷淳一, 張シシュン, 白髪誠一, 椿英顕, 多賀謙蔵, 北條稔郎, 永谷芳郎, 井上一朗：方杖ダンパー接合構造の設計例 その 28 階建て事務所建築 と 4 階建て工場建築の設計例, 日本建築学会近畿支部研究報告集, 第 46 号, 構造系, pp.249-252, 2006.6

24) 井上一朗，寺島雄一郎，聲高裕治，吉田文久：方杖ダンパーの標準仕様 之性能確認実験, 日本建築学会近畿支部研究報告集, 第 46 号, 構造系, pp.241-244, 2006.6 .

25）国土交通省住宅局建築指導課，国土交通省国土技術政策総合研究所，独立 行政法人建築研究所, 日本建築行政会議 : 2007 年版 建築物の構造関係技 術基準解説書, 2007.8.

26) 小川厚治, 多田元英 : 柱・梁接合部パネルの変形を考慮した静的・動的応 答解析プログラムの開発，第 17 回情報・システム・利用・技術シンポジ ウム論文集，pp.79-84，1994.12. 